\title{
Diversity of ectomycorrhizal fungi on two reclaimed surface mines differing in soil properties
}

\author{
Betsy S. Kurnik \\ West Virginia University
}

Follow this and additional works at: https://researchrepository.wvu.edu/etd

\section{Recommended Citation}

Kurnik, Betsy S., "Diversity of ectomycorrhizal fungi on two reclaimed surface mines differing in soil properties" (2000). Graduate Theses, Dissertations, and Problem Reports. 1126.

https://researchrepository.wvu.edu/etd/1126

This Thesis is protected by copyright and/or related rights. It has been brought to you by the The Research Repository @ WVU with permission from the rights-holder(s). You are free to use this Thesis in any way that is permitted by the copyright and related rights legislation that applies to your use. For other uses you must obtain permission from the rights-holder(s) directly, unless additional rights are indicated by a Creative Commons license in the record and/ or on the work itself. This Thesis has been accepted for inclusion in WVU Graduate Theses, Dissertations, and Problem Reports collection by an authorized administrator of The Research Repository @ WVU. For more information, please contact researchrepository@mail.wvu.edu. 


\title{
DIVERSITY OF ECTOMYCORRHIZAL FUNGI ON TWO RECLAIMED SURFACE MINES DIFFERING IN SOIL PROPERTIES
}

\author{
Betsy S. Kurnik
}

\begin{abstract}
A Thesis
Submitted to

The College of Agriculture, Forestry and Consumer Sciences

at

West Virginia University

in partial fulfillment of the requirements

for the degree of

Master of Science

in

Plant and Soil Sciences
\end{abstract}

Daniel Panaccione, Ph.D., Chair

Jonathan Cumming, Ph.D.

Joseph Morton, Ph.D.

2000

Morgantown, West Virginia 


\section{ABSTRACT \\ DIVERSITY OF ECTOMYCORRHIZAL FUNGI ON TWO RECLAIMED SURFACE MINES DIFFERING IN SOIL PROPERTIES}

\section{Betsy S. Kurnik}

I analyzed community structure of ectomycorrhizal fungi on white pine (Pinus strobus) on two reclaimed surface mines in eastern Ohio. One site was acidic and metal-stressed, the other was alkaline. Completely different community composition was found on the two sites by PCR/ITS/RFLP analyses of field collected mycorrhizae. However, Shannon-Wiener index values indicated that the two communities were equally diverse. A population of isolates of one species common to both sites was obtained from trap cultures planted with white pine. The identity of this species as Wilcoxina mikolae was established through DNA sequencing of the ITS region. The $W$. mikolae populations were further evaluated with in vitro studies determining the affects of aluminum and $\mathrm{pH}$. No clear differences between the two populations in response to aluminum and $\mathrm{pH}$ could be defined due to variation among isolates within populations. AFLP analysis showed that the populations from the two sites were genetically similar. 


\section{DEDICATION}

This thesis is dedicated to my parents, Joe and Melanie Thomas, and my aunt, Grace Thomas. 


\section{ACKNOWLEDGMENTS}

I would like to thank my committee chair, Dr. Daniel Panaccione, for his help with my research and writing of my thesis. Sincere appreciation is extended to Dr. Jonathan Cumming and Dr. Joseph Morton, members of my committee, for their contribution to my thesis.

I want express my appreciation to all professors, graduate students, and staff in the department for their assistance and support throughout the course of my graduate studies. I want to give sincere thanks to Nancy Sheets who faithfully supported me through my research and trials during graduate school. Her support and friendship was key in the completion of my thesis. I want to express many thanks to Dr. James Kotcon for his help with statistics and Jason Chereb for his assistance in data collection. I also want to thank Satish Bhatia, Prapassorn Damrongkool (Ked), Richard Johnson, Linda Johnson, Kelly Fleming, Krista De Fede, Kris Nichols, Bill Wheeler, and Bob Hendricks for their support and friendship.

Finally, I want to thank my family. My husband, Rich Kurnik, for the love, support, adventure, and motivation he brings to my life. My parents, Joe and Melanie Thomas, for teaching me that patience and hard work are critical in accomplishing task. To all my siblings, in-laws, nieces, and nephews, I thank you for your love and support. And last, but not least, I thank my aunt, Grace Thomas, for being a role model to me throughout my life. 


\section{TABLE OF CONTENTS}

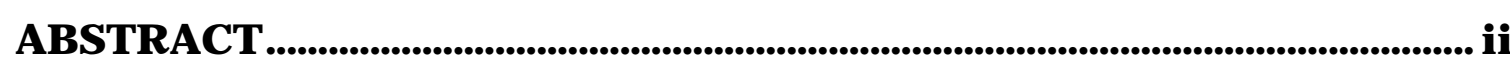

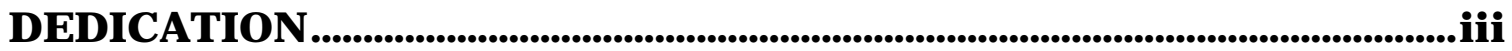

ACKNOWLEDGMENTS .............................................................................................................. iv

TABLE OF CONTENTS.........................................................................................................................v

LIST OF FIGURES.............................................................................................................................vii

LIST OF TABLES.................................................................................................................. viii

GENERAL INTRODUCTION _........................................................................... 1

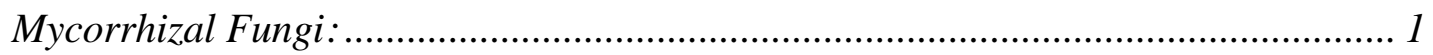

Ectomycorrhizal Fungi in Reclaimed Mine Lands: ................................................ 3

Assessing Ectomycorrhizal Fungal Diversity by DNA Fingerprinting: ..................... 5

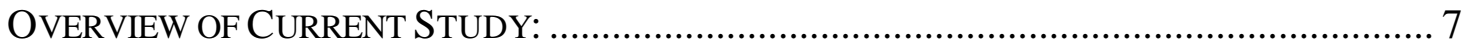

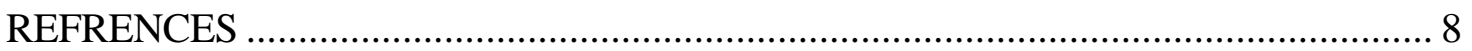

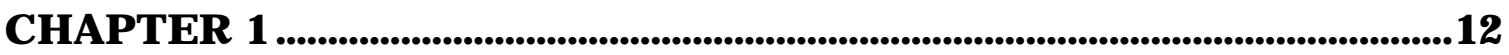

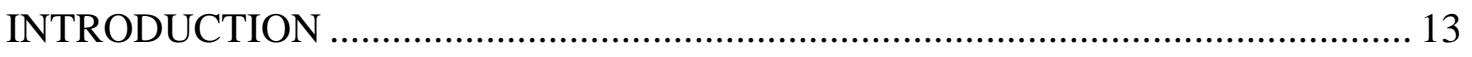

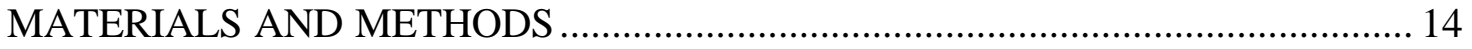

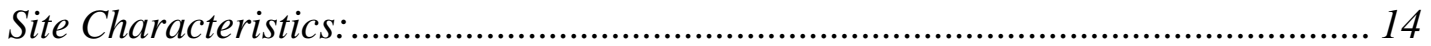

Characterization and Collection of Mycorrhizal Root Tips:..................................... 15

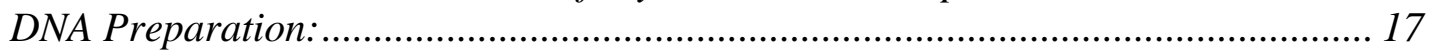

Polymerase Chain Reaction (PCR): ................................................................ 18

Restriction Fragment Length Polymorphism (RFLP): ......................................... 20

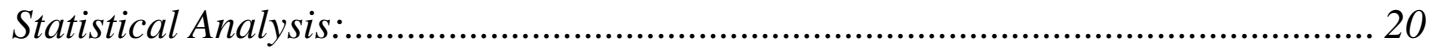

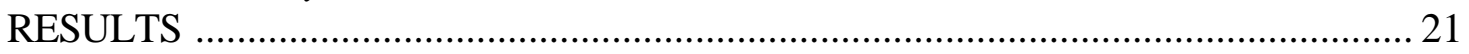

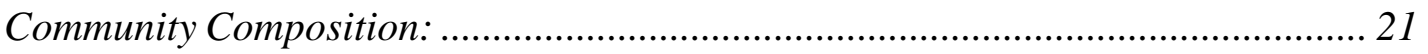

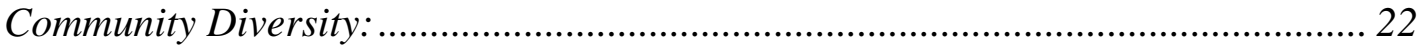

Trap Community Composition and Diversity:...................................................... 23

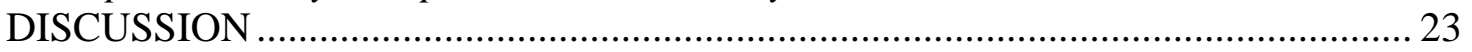

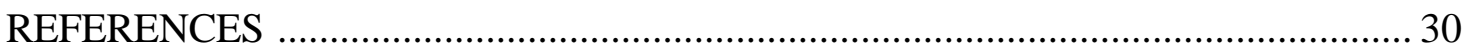

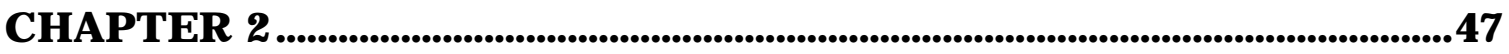

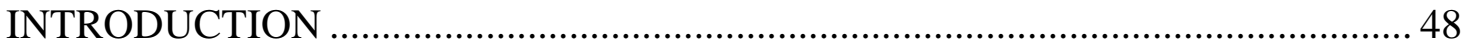

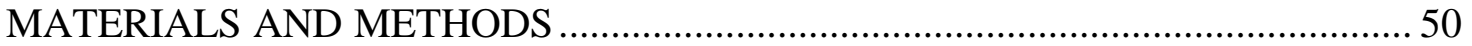

DNA Sequence Analysis of 'Rust Brown' Isolate: ................................................. 50

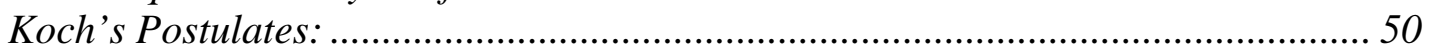

Amplified Fragment Length Polymorphism (AFLP) Analysis:............................... 51

Physiological Study: .................................................................................. 52

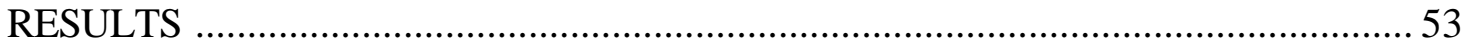

Identity of 'Rust Brown' Fungus: .................................................................... 53 
AFLP Analysis of W. mikolae Isolates from Acidic and Alkaline Sites: .................. 54

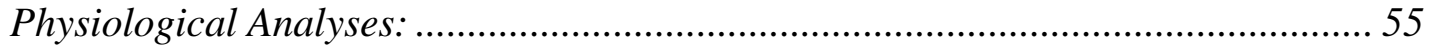

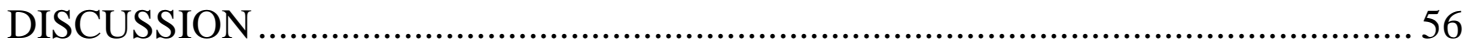

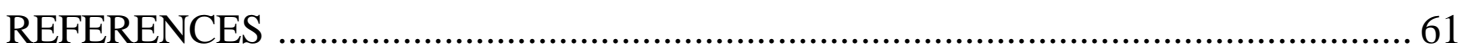

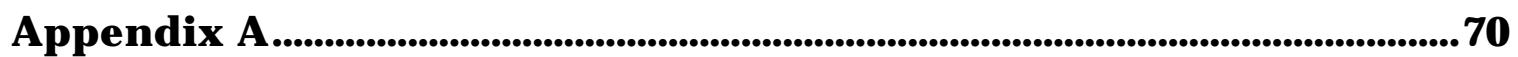

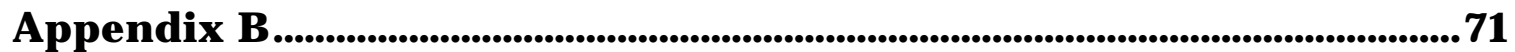

Appendix C.......................................................................................................................................72 


\section{LIST OF FIGURES}

Figure 1-1. Diagram of the ITS region. .......................................................................... 36

Figure 1-2. Amplification products of the ITS region. ................................................. 37

Figure 1-3. Morphotypes from trap cultures.......................................................... 39

Figure 1-4. Morphotypes from field collection. ........................................................ 39

Figure 1-5. RFLP analysis of the F12 morphotype...................................................... 40

Figure 1-6. RFLP analysis of the F10 morphotype......................................................... 41

Figure 1-7. Basidiomycete and non-Basidiomycete percentages................................ 43

Figure 1-8. RFLP analysis of the 'rust brown' isolates........................................... 46

Figure 2-1. DNA sequence comparison of the ITS region. .....................................65

Figure 2-2. Second gene ration of $W$. mikolae RFLP patterns....................................... 66

Figure 2-3. Isolate relationship based upon distance matrix. ..................................... 67

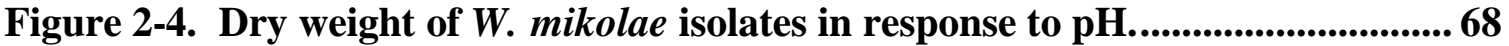

Figure 2-5. Dry of W. mikolae isolates in response to Al. ............................................ 69 


\section{LIST OF TABLES}

Table 1-1. Soil characteristics.............................................................................. 33

Table 1-2. Morphological categorization of trap culture roots..................................... 34

Table 1-3. Morphological categorization of field roots................................................. 35

Table 1-4. Distribution of fungal species.......................................................................... 42

Table 1-5. Distribution of Basidiomycetes...................................................................... 44

Table 1-6. Comparison of community diversity............................................................. 45 


\section{GENERAL INTRODUCTION}

\section{Mycorrhizal Fungi:}

The term mycorrhiza refers to a close relationship between a fungus and a root (Deacon, 1997). In most cases, the relationship is mutalistic whereby each organism receives life-sustaining material from the other. Seven different mycorrhizal relationships are formed, but the two most commonly found in nature are ectomycorrhizae and arbuscular endomycorrhizae (Allen et al., 1995; Alexopoulos et al., 1996).

A host plant receives several benefits from a mycorrhizal fungus symbiosis. The fungus promotes plant growth by exploring beyond the root zone of the plant into the soil with extramatrical mycelium to intercept nutrients and water (Danielson, 1991; Clarkson, 1985). Tolerance to drought, high soil temperature, and heavy metals made available by soil acidity are increased by mycorrhizal infection (Marx, 1980). Mycorrhizal fungi also benefit host plants by protecting the roots from plant pathogenic fungi (Morin et al., 1999; Duchesne et al., 1989; Marx, 1969) and nematodes (Smith and Read, 1999; Deacon, 1997). Mycorrhizal fungi receive benefits from the host plants in the form of carbohydrates and vitamins (Marx, 1975).

Ectomycorrhizal fungi are present in two phyla, the Basidiomycota and the Ascomycota (Marx, 1975). There have been approximately 5,400 
ectomycorrhizal species identified from 148 genera worldwide (Allen et al., 1995). Law and Lewis (1983) suggest the symbiotic relationship between ectomycorrhizal fungi and plants arose on a number of occasions.

In contrast, the arbuscular mycorrhizae, are presently classified in the phylum Zygomycota belonging to the order Glomales (Morton, 2000). Although the classification is currently under revision, 154 arbuscular fungal species have been described within seven genera (Morton, 2000). Evidence suggests that arbuscular fungi arose from a common ancestor (Morton, 2000).

Ectomycorrhizal fungal communities can be diverse, even when in association with host plants in communities with low diversity, such as a coniferous forest (Bruns, 1995; Hartley et al., 1997; Allen et al., 1995). Ectomycorrhizal community structure is influenced by host specificity (Egger, 1995). Many tree families, including the Pinaceae, Betulaceae, Fagaceae, Dipterocarpaceae, and most of the Mytaceae, Salicaceae and Cupressaceae associate with ectomycorrhizal fungi (Malloch et al., 1980). Schramm (1966) suggest that for seedling development, ectomycorrhizal colonization is essential.

Arbuscular mycorrhizal fungi are thought to have a relationship with nearly all agricultural, ornamental, forage, weed, and tropical plants, as well as cacti and many hardwood trees (Brundrett, 1991). Arbuscular mycorrhizal fungi are normally found in communities of low diversity, even when associated with plant communities of high diversity (Allen et al., 1995). 
The physiological relationships that these different types of mycorrhizal fungi have with their host plants are very similar. However, the physical mechanisms of how the hyphae interact with the host plants are unresolved. Ectomycorrhizal fungi cover the surface of feeder roots with a mantle or sheath of hyphae (Marx, 1975). A Hartig net forms by a hyphal network that grows intercellularly extending to the outermost root cortex cell layers (Alexopoulos et al., 1996). Hyphal strands extend out from the hyphal mantle to obtain nutrients and water from the soil (Danielson, 1991;

Clarkson, 1985). These materials are carried back to the Hartig net where an exchange between the plant and fungus presumably occurs (Deacon, 1997). Due to their need for a symbiotic relationship with a host tree, ectomycorrhizal fungi are rarely found in the environment in a free living state (Hartley et al., 1997).

Arbuscular fungi, however, grow intercellularly in root cells to branch and form intracellular arbuscles, which are sites of nutrient-exchange within cells, and sometimes vesicles, which are lipid storage structures (Smith and Read, 1999). Arbuscular mycorrhizae are obligate biotrophic fungi and cannot be grown in culture apart from their host plants (Deacon, 1997).

\section{Ectomycorrhizal Fungi in Reclaimed Mine Lands:}

Ectomycorrhizal fungi are beneficial partners to host plants, especially in stressed soil habitats. Some researchers suggest that certain fungi appear to adapt to living in stressful soil conditions (Marx and Artman, 1979), where 
they may play important roles in reducing plant uptake of toxic metals by accumulating the metals in the mycorrhizal hyphae (Turnau et al., 1996). An earlier study by Ingleby et al. (1985) suggests that stressed environments might limit mycorrhizal community diversity. This study recorded restricted diversity of fruiting bodies of ectomycorrhizal fungi on abandoned poor soils.

Since 1930, approximately 6 million acres have been disturbed by coal mining operations in the United States (Zeleznik and Skousen, 1996). The contour of the land is changed by surface mining, which causes the geologic and hydrologic features to be altered (Gillis, 1991). Surface mining is disruptive to biological communities because the operation consists of removing the overburden (soil above the coal) by blasting to expose coal veins, removing coal, and then replacing overburden (Skousen, personal communication).

Mine soils are associated with low fertility, low organic matter, few nutrient reserves, low moisture-holding capacity, excessive leaching, erosion, and possibly unfavorable chemical characteristics (Jurgensen, 1978). Danielson (1991) described unreclaimed mine spoils as adverse environments for plant growth.

In 1977, the federal government passed the Surface Mining Control and Reclamation Act (SMCRA), which required that all land mined for coal must be reclaimed in a manner such that the land resembles the premining 
condition (Gillis, 1991). SMCRA required land restoration to the premining use and/or level of productivity (Barnhisel and Hower, 1997).

Biological communities are considered a complex of species interacting and changing through the addition or loss of species (Egger 1995). The practice of surface mining leads to disruption of the original biological communities. One researcher considered strip-mined lands to be a biological desert in comparison to the biological status of the original profile (Marx, 1975). Some of the original topsoil may be mixed throughout, but this is not enough to bring the land back to normalcy.

Suitable rooting media for vegetation is critical for reconstruction of mined land (Barnhisel and Hower, 1997). In present day reclamation, soil layers are replaced in the order in which they were removed to aid in revegetation of the surface mine (Gould et al., 1996). The soil medium selected for the surface should provide physical and chemical properties suitable for postmining land use (Skousen and Zipper, 1996).

\section{Assessing Ectomycorrhizal Fungal Diversity by DNA Fingerprinting:}

To assess diversity of an ectomycorrhizal fungus community on reclaimed mines, or any site, researchers must use an appropriate strategy. A great deal of concern has been expressed about the validity of counting fungal reproductive structures to assess the diversity of fungi in a given area, due to the constraints of time and weather (Gardes and Bruns, 1996; Danielson and Pruden, 1989). Gardes and Bruns (1996) found that some of 
the most common species fruiting above ground were seldom found on roots below ground. They found that more than half of the mycorrhizal fungi colonizing roots were not represented aboveground during the three-year period of their study. In another study, of 47 fungal species producing sporocarps over 6 years, only 7 produced sporocarps every year, and almost half of the species produced fruiting bodies in any given year (Dahlberg et al., 1997). Fruiting bodies are indicative of species being present in the soil, but the absence of fruiting bodies is not indicative of the absence of mycorrhizal colonization (Gardes and Bruns, 1996).

DNA fingerprinting allows identification of mycorrhizal fungi on host plants even in the absence of fruiting bodies. DNA amplification is possible from small mycorrhizal tips using the polymerase chain reaction (PCR). The use of PCR increases sensitivity in detecting DNA sequences because small volumes of DNA may be targeted (Timonen et al., 1997; Gardes and Bruns, 1996; Gardes and Bruns, 1993; Henrion et al., 1992). PCR directly from mycorrhizal root tips has given a more definitive measure of ectomycorrhizal fungi colonizing the tree roots (Gardes and Bruns, 1996).

Amplifying the internal transcribed spacer (ITS) region of ribosomal DNA, followed by restriction fragment length polymorphism (RFLP) analysis of the amplified ITS regions has been very useful in distinguishing mycorrhizal fungal species on roots (Erland et al., 1994; Gardes and Bruns, 1993; Gardes et al., 1991; Henrion et al., 1992; Gehring et al., 1998; 
Gandeboeuf et al., 1997; Timonen et al., 1997; Dahlberg et al., 1997). In general, RFLP analysis of the ITS region provides species level identification (Guidot et al., 1999). Bonfante et al. (1997) detected variability in the RFLPs of the amplified ITS regions between species of Suillus, but little difference within a species.

In cases where differences among isolates within a species need to be determined, more powerful DNA fingerprinting techniques such as amplified fragment length polymorphism (AFLP) can be applied. AFLP combines PCR and RFLP to reveal significant levels of DNA polymorphism (Vos et al., 1995). AFLP is considered to be a robust and reliable molecular marker assay detecting DNA polymorphism at a much higher level of resolution (Loh et al., 1999). It has been used successfully with many plants to detect intraspecific variability (Loh et al., 1999; Barrett and Kidwell, 1998).

\section{Overview of Current Study:}

In this thesis I describe a series of studies performed to investigate ectomycorrhizal diversity from 2 reclaimed surface mines in eastern Ohio differing in soil properties. In chapter one, I describe community level diversity in field and trap cultures of ectomycorrhizal fungi on an acidic, aluminum-rich site (Dundee, Ohio) and an alkaline, non-metal stressed site (Georgetown, Ohio). Chapter two summarizes the intraspecific variation within isolates of one species from Dundee and Georgetown, Ohio. 


\section{REFRENCES}

Alexopoulos, C.J., C.W. Mims, and M. Blackwell. 1996. Phylum Basidiomycota Order Agaricales. In Introductory Mycology. Edited by D. Harris and S. Russell. John Wiley \& Sons, Inc., New York. pp. 515-517.

Allen, E.B., M.F. Allen, D.J. Helm, J.M. Trappe, R. Molina, and E. Rincon. 1995. Patterns and regulation of mycorrhizal plant and fungal diversity. Plant and Soil 170: 47-62.

Barnhisel, R.I. and J.M. Hower. 1997. Coal surface mine reclamation in the eastern United States: The revegetation of disturbed lands to hayland/pasture or cropland. Advances in Agronomy 61: 233-275.

Barrett, B.A. and K.K. Kidwell. 1998. AFLP-based genetic diversity assessment among wheat cultivars from the Pacific Northwest. Crop Sci. 38: 1261-1271.

Bonfante, P., L. Lanfranco, V. Cometti, and A. Genre. 1997. Inter- and intraspecific variability in strains of the ectomycorrhizal fungus Suillus as revealed by molecular techniques. Microbiol. Res. 152: 287-292.

Bruns, T. 1995. Thoughts on the processes that maintain local species diversity of ectomycorrhizal fungi. Plant and Soil 170: 63-73.

Brundrett, M. 1991. Mycorrhizas in natural ecosystems. Advances in Ecological Research 21: 171-313.

Clarkson, D.T. 1985. Factors affecting mineral nutrient acquisition by plants. Ann. Rev. Plant Physiol. 36: 77-115.

Dahlberg, A., L. Jonsson, and J. Nylund. 1997. Species diversity and distribution of biomass above and below ground among ectomycorrhizal fungi in an old-growth Norway spruce forest in south Sweden. Can. J. Bot. 75: 1323-1335.

Danielson, R.M. 1991. Temporal changes and effects of amendments on the occurrence of sheathing (ecto-) mycorrhizas on conifers growing in oil sands tailings and coal spoil. Agriculture, Ecosystems and Environment 35: 261281.

Danielson, R.M. and M. Pruden. 1989. The ectomycorrhizal status of urban spruce. Mycologia 81: 335-341. 
Deacon, J.W. 1997. Fungi as plant parasites. In Modern Mycology. University Press, Cambridge. pp. 246-252.

Duchesne, L.C., B.E. Ellis, and R.L. Peterson. 1989. Disease suppression by the ectomycorrhizal fungus Paxillus invoutus: contribution of oxalic acid. Can. J. Bot. 67: 2726-2730.

Egger, K.N. 1995. Molecular analysis of ectomycorrhizal fungal communities. Can. J. Bot. 73: S1415-S1422.

Erland, S., B. Henrion, F. Martin, L.A. Glover, and I.J. Alexander. 1994. Identification of the ectomycorrhizal Basidiomycete Tylospora fibrillosa Donk by RFLP analysis of the PCR-amplified ITS and IGS regions of ribosomal DNA. New Phytol. 126: 525-532.

Gandeboeuf, D., C. Dupre, P. Roeckel-Drevet, P. Nicolas, and G. Chevalier. 1997. Typeing Tuber ectomycorrhizae by polymerase chain amplification of the internal transcribed spacer of rDNA and the sequence characterized amplified region markers. Can. J. Microbiol. 43: 723-728.

Gardes, M. and T.D. Bruns. 1996. Community structure of ectomycorrhizal fungi in a Pinus muricata forest: above- and below-ground views. Can. J. Bot. 74: 1572-1583.

Gardes, M. and T.D. Bruns. 1993. ITS primers with enhanced specificity for Basidiomycetes-application to the identification of mycorrhizae and rusts. Molecular Ecology 2: 113-118.

Gardes, M., T.J. White, J.A. Fortin, T.D. Bruns, and J.W. Taylor. 1991. Identification of indigenous and introduced symbiotic fungi in ectomycrrhizae by amplification of nuclear and mitochondrial ribosomal DNA. Can. J. Bot. 69: 180-190.

Gehring, C.A., T.C. Theimer, T.G. Whitham, and P. Keim. 1998.

Ectomycorrhizal fungal community structure of pinyon pines growing in two environmental extremes. Ecology 79: 1562-1572.

Gillis, A.M. 1991. Bring back the land: Ecologist evaluate reclamation success on western coal lands. Bioscience 41: 68-71.

Gould, A.B., J.W. Hendrix, and R.S. Ferriss. 1996. Relationship of mycorrhizal activity to time following reclamation of surface mine land in western Kentucky. I. Propagule and spore population densities. Can. J. Bot. 74: 247-261. 
Guidot, A., E. Lumini, J.C. Debaud, and R. Marmeisse. 1999. The nuclear ribosomal DNA intergenic spacer as a target sequence to study intraspecific diversity of the ectomycorrhizal Basidiomycete Hebeloma cylindrosporum directly on Pinus root system. Appl. Environ. Microbiol. 65: 903-909.

Hartley, J., J.W.G. Cairney, and A.A. Meharg. 1997. Do ectomycorrhizal fungi exhibit adaptive tolerance to potentially toxic metals in the environment? Plant and Soil 189: 303-319.

Henrion, B., F. Le Tacon, and F. Martin. 1992. Rapid identification of genetic variation of ectomycorrhizal fungi by amplification of ribosomal RNA genes. New Phytol. 122: 289-298.

Ingleby, K., F.T. Last, and P.A. 1985. Vertical distribution and temperature relations of sheathing mycorrhizas of Betula spp. growing on coal spoil. Forest Ecology Management 12: 279-285.

Jurgensen, M.F. 1978. Microorganisms and the reclamation of mine wastes. In Forest Soils and Land Use. Edited by C. T. Youngberg. Department of Forestry and Wood Science, Colorado State University, Fort Collins, CO. pp. 251-286.

Law, R. and D.H. Lewis. 1983. Biotic environments and the maintenance of sex-some evidence from mutualistic symbioses. Biological Journal of the Linnean Society 20: 249-276.

Loh, J.P., R. Kiew, A. Kee, L.H. Gan, and Y.Y. Gan. 1999. Amplified fragment length polymorphism (AFLP) provides molecular markers for the identification of Caladium bicolor cultivars. Ann. Bot. 84: 155-161.

Malloch, D.W., K.A. Pirozynski, and P.H. Raven. 1980. Ecological and evolutionary significance of mycorrhizal symbioses in vascular plants (A Review). Proc. Natl. Acad. Sci. USA. 77: 2113-2118.

Marx, D.H. 1980. Role of mycorrhizae in forestation of surface mines. In Trees for Reclamation. Interstate Mining Compact Commission and U.S.D.A. Forest Service General, Technical Report NE 61. Lexington, Kentucky. pp. 109-116.

Marx, D.H. and J.D. Artman. 1979. Pisolithus tinctorius ectomycorrhizae improve survival and growth of pine seedlings on acid coal spoils in Kentucky and Virginia. Reclamation Review 2: 23-31. 
Marx, D.H. 1975. Mycorrhizae and establishment of trees on strip-mined land. Ohio J. Sci. 75: 288-297.

Marx, D.H. 1969. The influence of ectotrophic mycorrhizal fungi on the resistance of pine roots to pathogenic infections. I. Antagonism of mycorrhizal fungi to root pathogenic fungi and soil bacteria. Phytopathology 59: 153-163.

Morin, C., J. Samson, and M. Dessureault. 1999. Protection of black spruce seedlings against Cylindrocladium root rot with ectomycorrhizal fungi. Can. J. Bot. 77: 169-174.

Morton, J.B. 2000. Evolution of endophytism in arbuscular mycorrhizal fungi Glomales. In Microbial Endophytes. Edited by C.W. Bacon and J.F. White, Jr. Marcel Dekker, Inc., New York. pp. 121-140.

Schramm, J.E. 1966. Plant colonization studies on black wastes from anthracite mining in Pennsylvania. Amer. Philoso. Soc. 56: 1-194.

Skousen, J. and C.E. Zipper. 1996. Revegetation species and practices. Virginia Cooperative Extension Publication 460-122.

Smith, S.E. and D.J. Read. 1997. Mycorrhizal Symbiosis. J \& L Composition Ltd, Filey, North Yorkshire.

Timonen, S., H. Tammi, and R. Sen. 1997. Characterization of the host genotype and fungal diversity in Scots pine ectomycorrhiza from natural humus microcosms using isozyme and PCR-RFLP analyses. New Phytol. 135: 313-323.

Turnau, K., I. Kottke, and J. Dexheimer. 1996. Toxic element filtering in Rhizopogon roseolus / Pinus sylvestris mycorrhizas collected from calamine dumps. Mycol. Res. 100: 16-22.

Vos, P., R. Hogers, M. Bleeker, M. Reijans, T. van de Lee, M. Hornes, A. Freijters, J. Pot, M. Kuiper, and M. Zabeau. 1995. AFLP: a new technique for DNA fingerprinting. Nucleic Acids Research 23: 4407-4414.

Zeleznik, J.D. and J.G. Skousen. 1996. Survival of three tree species on old reclaimed surface mines in Ohio. J. Environ. Qual. 25: 1429-1435. 


\section{CHAPTER 1}

Ectomycorrhizal fungal community biodiversity on an acidic, Al-rich site (Dundee) and an alkaline, non-metal stressed site (Georgetown). 


\section{INTRODUCTION}

Surface mining disrupts microbial activity and destroys vegetation (Gillis, 1991). Gould et al. (1996) found that arbuscular mycorrhizal inoculum density was extremely low after the first year of reclaiming abandoned surface mines in Kentucky and increased slowly in the second and third years after reclamation. Surface mine reclamation often leads to low soil $\mathrm{pH}$, inadequate moisture retention, and compaction problems (Barnhisel and Hower, 1997). Soil pH and moisture can influence capacity for ectomycorrhizal development in host plants (Marx, 1980). Furthermore, compaction impedes root growth (Barnhisel and Hower, 1997) thus limiting the extent of ectomycorrhizal colonization on feeder roots (Marx, 1980).

Reestablishing a stable landscape that has a state of usefulness is the primary goal of reclamation (Barnhisel and Hower, 1997). Currently, grasses and legumes are preferred over tree planting because they quickly control erosion and provide a quick economic return (Zeleznik and Skousen, 1996). Tree planting has been used extensively in the past and provides long-term stabilization, though the process is slow (Zeleznik and Skousen, 1996).

The objective of this current study was to assess biodiversity of ectomycorrhizal fungal communities on an acidic, aluminum-rich site (Dundee, $\mathrm{OH}$ ) and an alkaline, non-metal stressed site (Georgetown, $\mathrm{OH}$ ) reclaimed with eastern white pine. We hypothesized that the fungal communities would differ and that the acidic, aluminum-rich soils would 
restrict the diversity of fungi on that site. We also compared efficacy of detecting diversity in root tips derived from trap cultures compared to fieldcollected mycorrhizal root tips.

\section{MATERIALS AND METHODS}

\section{Site Characteristics:}

The surface mining operations located near Georgetown and Dundee, Ohio consisted of the removal of overburden, the extraction of coal, and the replacement of overburden into mined cuts in a series of ridges and troughs (Zeleznik and Skousen, 1996). During reclamation on some of the Georgetown plots, bulldozers leveled the ridges and troughs. In other plots of Georgetown and all Dundee plots, no leveling occurred. In 1946 these surface mines were reclaimed with tree planting (Zeleznik and Skousen, 1996).

Georgetown and Dundee sites were previously divided into 1.2 ha replicated plots planted with various tree species. Among the tree species was eastern white pine (Pinus strobus), which forms obligate associations with ectomycorrhizal fungi. The trees came from common nursery stock so that common fungal species were present at the time of outplanting, which minimized variation for initial fungal populations. Ten trees were chosen on each of three plots for evaluation. Zeleznik and Skousen (1996) analyzed 10 soil samples from each plot in 1992 to determine overall chemical characteristics of the soils on each site (Table 1-1). 


\section{Characterization and Collection of Mycorrhizal Root Tips:}

Ectomycorrhizae were collected and categorized by examining tree seedling roots from trap cultures and from tree roots collected from the field.

\section{Trap Cultures:}

Pot cultures containing field soil and planted with a mycotrophic host provide a method to trap out natural ectomycorrhizal fungi. Three soil cores (approximately $300 \mathrm{ml}$ each) were taken about $1 \mathrm{~m}$ from the trunk of each of ten trees per plot at each site. Soils were transported to the lab and stored at $4^{\circ} \mathrm{C}$ until samples were used. The field soil was homogenized by chopping; mixed with sand 1:2(v/v); and, placed in $300 \mathrm{~cm}^{3}$ deepots (Stuewe and Sons, Corvallis, OR). Individual tree and plot identity were maintained. Before germination, white pine seeds were surface sterilized with tap water for 60 minutes, $0.1 \%$ tween- 80 for 60 minutes, an additional rinse with tap water for 60 minutes, a $30 \%$ hydrogen peroxide rinse followed by a distilled, sterile water rinse. Seeds were stratified in sterile perlite that was dampened for 60 days. The flats containing the seeds were then moved to a growth chamber where there was a 14 hour light period at $24^{\circ} \mathrm{C}$ followed by a 10 hour light period at $19^{\circ} \mathrm{C}$, allowed to germinate in the perlite and transplanted after approximately 4 weeks of growth.

White pine seedlings were transplanted to deepots within 1 week of each other and pots were placed in a greenhouse. Plants were watered with 
an artificial rain solution (Lee and Weber, 1979) and grew for approximately 3 months before being harvested.

At harvest trees were loosened from the cones by rolling the cone on a countertop, after which roots and soil were gently pulled from the cone. Loose soil was carefully shaken from the roots, after which the root system was submerged in approximately $200 \mathrm{ml}$ of tap water to remove adherent soil. All trees were harvested over a 3-week period.

Roots were examined under a dissecting microscope and mycorrhizal root tips were placed into categories based upon their morphological characteristics (Table 1-2). The number of mycorrhizal root tips per plant was also recorded. Mycorrhizal root tips then were excised, surface-sterilized with $30 \% \mathrm{H}_{2} \mathrm{O}_{2}$ and placed on modified Melin Norkins (MMN) medium (Marks, 1969). Potato dextrose agar (PDA; Annis and Panaccione, 1998) also was used for later transfers. When several mycorrhizal tips in the same category were found on one plant, the tips were frozen in $\mathrm{a}-80^{\circ} \mathrm{C}$ freezer for later DNA extraction.

\section{Field Root Collection:}

Roots of trees sampled for trap cultures also were examined for mycorrhizal root tips in the field. Approximately $1 \mathrm{~m}$ from the base of the tree, organic matter was removed to expose the topsoil layer. Roots near the soil surface were carefully removed and placed in plastic bags for transport back to the lab. 
Once in the laboratory, root length was measured and roots were examined in the same manner described above for trap cultures.

Morphological characteristics of root tips were different than those found in the trap cultures, so that different criteria were used to characterize them (Table 1-3). Tips were frozen and stored in the same manner as described previously.

\section{DNA Preparation:}

Over the course of this study, three different DNA extraction protocols were used. Each of the protocols is summarized below. Miniprep Extraction Method:

Gardes and Bruns (1993) developed the miniprep extraction method for DNA extraction from fungal root tips (Appendix A). Three-hundred $\mu \mathrm{l}$ of 2X CTAB extraction buffer [2\% (w/v) CTAB, $100 \mathrm{mM}$ Tris HCL, $20 \mathrm{mM}$ EDTA, and 1.4 M NaCl] was added to frozen mycorrhizal root tips in a 1.7-ml microcentrifuge tube. The suspended sample was frozen at $-70^{\circ} \mathrm{C}$ and thawed on a heat block at $65^{\circ} \mathrm{C}$ three times. After the final thaw, the sample was crushed with a micropestle and incubated at $65^{\circ} \mathrm{C}$ for 30 to 60 minutes. One volume (approximately $300 \mu \mathrm{l}$ ) of chloroform was added to each sample and mixed briefly by vortexing. Samples were centrifuged for 10 minutes. DNA in the top layer was precipitated with cold isopropanol, collected by centrifugation, and washed with $70 \%$ ice-cold ethanol. The pellet was suspended in $40-60 \mu \mathrm{l}$ of $0.1 \mathrm{X} \mathrm{TE}$ ( $1 \mathrm{mM}$ Tris $\mathrm{pH}$ 8.0, 0.1 mM EDTA). 
Samples were diluted 1:5, 1:10, or 1:25 in a $50 \mu$ l Polymerase Chain Reaction (PCR).

Modified Miniprep Extraction Method, GeneClean Protocol:

Samples were ground in $2 \mathrm{X}$ CTAB buffer and extracted with chloroform as previously described (Appendix B). The top phase after chloroform extraction was purified with the GeneClean Kit (Bio101, Vista, CA). Samples were diluted as needed for PCR.

\section{Modified Miniprep Extraction Method, GeneClean Spin Protocol:}

Samples were ground in $2 \mathrm{X}$ CTAB buffer and extracted with chloroform as previously described (Appendix C). The top phase after chloroform extraction was purified with GeneClean Spin Kit (Bio101, Vista, CA). After purification, samples were diluted as needed for PCR.

\section{Polymerase Chain Reaction (PCR):}

\section{Preparation:}

PCR was performed in $50 \mu \mathrm{l}$ reactions containing $10 \mathrm{mM}$ Tris-HCl $\mathrm{pH}$ 9.0, $50 \mathrm{mM} \mathrm{KCl}, 0.1 \% \mathrm{v} / \mathrm{v}$ Triton-X100, $1.5 \mathrm{mM} \mathrm{MgCl} 2,200 \mu \mathrm{M}$ each of deoxyribonucleotide triphosphates (dATP, dCTP, dGTP, dTTP; Promega Biotech, Madison, WI), $1 \mu \mathrm{M}$ each of two oligonucleotide primers (GIBCO BRL Custom Primers, Gaithersburg, MD; described below), 0.5 units of Taq DNA polymerase (Promega Biotech, Madison, WI), and the desired amount of genomic DNA. The volume of DNA added ranged from 1 to $10 \mu \mathrm{l}$ among various samples. 
The internal transcribed spacer (ITS) region of the ribosomal DNA (rDNA; Fig. 1-1) of each sample was amplified using a general primer combination of ITS1 (5'-TCCGTAGGTGAACCTGCGG-3') and ITS4 (5'TCCTCCGCTATTGATATGC-3'), which anneals to DNA of a wide range of fungi (White et al., 1990). Production of a DNA fragment from primers ITS1/ITS4 demonstrated fungal rDNA had been successfully isolated from the mycorrhizal root tip (Fig. 1-2a, 1-2b). The primer combination of ITS1 and ITS4B (5'-CAGGAGACTTGTACACGGTCCAG-3') was used as an indicator of Basidiomycetes (Gardes and Bruns, 1993). Figure 1-2c indicates that in lane 3, A439 was a Basidiomycete and A423 (lane 4) was not. Figure 1-1 illustrates the approximate location of the primers on the rDNA. PCR Temperature Cycles:

The PCR reactions were incubated in a programmable heat block (Hybaid, PCR Sprint) through 35 cycles of the following series of steps. The initial denaturing was at $95^{\circ} \mathrm{C}$ for $85 \mathrm{~s}$ followed by 13 cycles of $95^{\circ} \mathrm{C}$ for $35 \mathrm{~s}$, $55^{\circ} \mathrm{C}$ for $55 \mathrm{~s}$, and $72^{\circ} \mathrm{C}$ for $45 \mathrm{~s}$. Cycles $14-26$ were $95^{\circ} \mathrm{C}$ for $35 \mathrm{~s}, 55^{\circ} \mathrm{C}$ for $55 \mathrm{~s}$, and $72^{\circ} \mathrm{C}$ for $120 \mathrm{~s}$. Cycles $27-35$ followed the same pattern with $95^{\circ} \mathrm{C}$ for $35 \mathrm{~s}, 55^{\circ} \mathrm{C}$ for $55 \mathrm{~s}$, but $72^{\circ} \mathrm{C}$ for $180 \mathrm{~s}$. Upon completion of the 35 cycles, samples were incubated at $72^{\circ} \mathrm{C}$ for an additional 10 minutes. 


\section{Electrophoresis:}

PCR products were examined by electrophoresis through 1.5\% agarose gels (Sigma, St. Louis, MO), stained with ethidium bromide (BioRad, Richmond, CA), and photographed under ultraviolet (UV) light.

\section{Restriction Fragment Length Polymorphism (RFLP):}

Aliquots of amplified ITS regions were digested separately for $3 \mathrm{~h}$ with 2 enzymes, Sau 3AI and Nla III (New England Bio Labs, Beverly, MA). Samples were loaded onto a 2.0\% agarose gel (Sigma, St. Louis, MO) and electrophoresed as described previously. RFLP patterns were photographed under UV illumination. Root tips were considered to contain the same fungal species if RFLP patterns were identical for both enzymes (Gardes and Bruns, 1996; Gehring et al. 1998).

\section{Statistical Analysis:}

Diversity was calculated with the Shannon-Wiener index $(\mathrm{H})$

$$
\mathrm{H}=-\operatorname{sum}\left(\mathrm{P}_{\mathrm{i} *} \log \left[\mathrm{P}_{\mathrm{i}}\right]\right)
$$

where $\mathrm{P}_{\mathrm{i}}$ is the proportion of the $i$ th species among all species (Bills et al., 1986). Species richness (S) was calculated by totaling the number of species. To measure the relative abundance of species, species evenness (E) was computed by $\mathrm{E}=\mathrm{H} / \log (\mathrm{S})$. The diversity index and species richness for the two sites were compared using t-tests. 


\section{RESULTS}

\section{Community Composition:}

The mycorrhizal root tips collected in the field were counted and categorized according to visual likeness (Table 1-3, Fig. 1-4). Individual (or different) fungal species associated with field-isolated root tips were investigated by RFLP analysis of PCR amplified rDNA. Mycorrhizal root tips grouped into a morphological class produced either identical (Fig. 1-5) or different (Fig. 1-6) RFLPs. RFLP patterns identified 31 fungal species (Table 1-4). The range of genetic diversity greatly exceeded that of morphological differences in some groups. For example, eleven species were separated from the F1 morphotype (Tables 3, 4), conversely other morphotypes were homogenous, such as F2, F4, F6, F8, F11, F12, and F14. Designations, such as F1A, F1B, F1C as they appear in subsequent tables, for example, represent different species originally considered F1 morphotype.

The fungal communities exemplified by PCR/ITS/RFLP analyses in field-collected roots from the two sites were completely different. F1 was the only common morphotype to both sites, however, evaluation with PCR/ITS/RFLP declared no common species to the two sites. Table 1-4 lists the 31 identified fungal species and the plots on which the fungi were found. No fungal species found at Georgetown were found at Dundee (Table 1-4).

F2 and F12 were the most frequently encountered species at Georgetown and Dundee, respectively. Of $24.05 \mathrm{~m}$ of roots examined from 15 
trees at Georgetown, 2309 mycorrhizal tips were found and $41 \%$ of these were F2 species. DNA extraction was attempted on twenty F2 mycorrhizal tip samples and RFLP patterns suggested that these root tips were identical. F2 mycorrhizal tips were cultured and RFLP patterns from samples indicated that cultured isolates of $\mathrm{F} 2$ were identical to fungi in the mycorrhizal tips. From Dundee samples, of $20.66 \mathrm{~m}$ of roots from 15 trees yielded 1119 mycorrhizal tips, of which $65 \%$ of the F12 species. RFLP patterns of F12 root tip samples were clearly identical suggesting the visual grouping of the F12 morphotype was correct (Fig. 1-5). The F1 morphotype was observed in 874 mycorrhizal tips, but yielded 11 different fungal species from 45 samples (Table 1-4).

Of the 30 fungal species investigated, 19 (63\%) were Basidiomycete fungi and 11 (37\%) were of some other class (Fig. 1-7). Basidiomycete fungi dominated at only one plot at Georgetown and two plots at Dundee. Otherwise, Basidiomycete and non-Basidiomycete fungi were in equal proportion (Table 1-5). Of all fungal species at Dundee and Georgetown, 69\% and $57 \%$ were Basidiomycetes, respectively.

\section{Community Diversity:}

Even though the fungal species at each site were genetically and morphologically distinct, community diversity was not significantly different (Table 1-6). The Shannon-Wiener Index values for the two sites were not different between the two communities (Table 1-6). Species richness varied 
among plots within each site especially Georgetown, but no significant difference was detected between sites (Table 1-6). Furthermore, species evenness did not differ between sites nor between plots at each site (Table 1$6)$.

\section{Trap Community Composition and Diversity:}

Genetic diversity of ectomycorrhizal fungi collected from trap cultures was very low. RFLPs revealed only 2 fungal species, even though 10 morphotypes were originally distinguished (Table 1-2, Fig. 1-3). The species T10 was found on only 1 seedling from Dundee, but the species designated 'rust brown' was found on all ten seedlings planted in soil from all 6 plots. Colonies of this fungus growing on MMN and PDA agar-based media had a fluffy, rust-brown morphology. ITS-RFLP fingerprints obtained from mycorrhizal tips and axenic culture of this fungus were identical (Fig. 1-8).

Mycorrhizal tips recovered from trap seedlings planted in soil from Dundee were $61 \%$ higher in number than those from Georgetown (4254 and 2587, respectively). Georgetown trap cultures averaged 89.2 tips per seedling, whereas Dundee trap cultures averaged 151.9 tips per seedling.

\section{DISCUSSION}

The objective of this chapter was to assess the biodiversity of ectomycorrhizal fungal communities on an acidic, Al-rich site (Dundee, Ohio) and an alkaline, non-metal stressed site (Georgetown, Ohio). We hypothesized that due to pressure imposed by the concentration of $\mathrm{Al}$, we 
would find more diversity on the alkaline site. However, the ShannonWiener Index values suggested no difference in the diversity of the two sites (Table 1-6). A previous study suggested that as the stand age increased the ectomycorrhizal diversity also increased (Bradbury et al., 1998). All trees on both these sites were approximately 55 years old allowing ample time for a diverse population to develop.

A similar study of ectomycorrhizal fungal diversity on serpentine (stressed) and non-serpentine (non-stressed) sites in Maryland also yielded similar Shannon-Wiener Index values (Cumming and Panaccione, personal communication). However, in that study, ectomycorrhizal community diversity was constrained on the serpentine as compared to the nonserpentine site. Bills et al. (1986) compared two forest types, spruce and hardwood, where they found consistency in the total number of species between their two sites. Gehring et al. (1998) found their cinder (stressed) sites averaged 16.7 ectomycorrhizal types and sandy-loam (non-stressed) sites averaged 17 ectomycorrhizal types. Our results are consistent with those of the previous studies in that the Dundee site totaled 16 species and Georgetown had a total of 15 species.

We expected differences in the community composition but hypothesized that some species would overlap between the two sites. This was not the case; instead, the community structure was completely different. The expected overlapping fungal taxa were not found even though the trees 
came from the same nursery stock. Observation of overlapping species in other ectomycorrhizal fungal diversity studies, however, has been common (Baxter et al., 1999; Gehring et al., 1998; Bills et al., 1986; Cumming and Panaccione, personal communication; Bradbury et al., 1998; Kranabetter and Wylie, 1998; Gardes and Bruns, 1996).

The lack of observed overlap might have been due to climatic conditions, geography, or soil factors. Overlap might have been detected if we had the opportunity to assess sporocarp production. Due to drought conditions, however, few sporocarps were found.

The distance of approximately $75 \mathrm{~km}$ between Georgetown and Dundee may have been great enough to limit fungal spore dispersal, therefore leading to no overlapping species. Allen et al. (1995) hypothesized that ectomycorrhizal fungi may be susceptible to biogeographic limitations on their dispersal. Gehring et al. (1998), as mentioned previously, found some overlapping species, but the site locations for that study were within a $20 \mathrm{~km}^{2}$ region. Cumming and Panaccione (personal communication) found four overlapping species, but plots were relatively close together (within $4 \mathrm{~km}^{2}$ ).

Soil conditions also may provide important filtering effects on community structure and must be considered when hypothesizing the reasons for the lack of overlapping species. Kranabetter and Wylie (1998) suggested that fungal distribution might reflect soil interactions in the relationship between ectomycorrhizal fungi and tree nutrition and health. 
Allen et al. (1995) suggested that fungi adapt to their local soil and climatic conditions. Although climatically they are similar, local soil conditions between Dundee and Georgetown were very different (Table 1-1).

Zeleznik and Skousen (1996) found large differences in soil chemical properties (Table 1-1) when they examined the survival and growth of white pine at Georgetown and Dundee. White pine is assumed to be better adapted to soils of $\mathrm{pH}$ is 5.5 or less (Skousen et al., 1994), so that pine growth and survival would be expected to be higher at Dundee than Georgetown. However, tree growth did not differ and survivability was lower at Dundee (Zeleznik and Skousen 1996), possibly due to other constraints, such as Al stress.

Hartley et al. (1997) have suggested that ectomycorrhizal fungi vary in their ability to reduce metal sensitivity to the host plant. One study found that depending on the mycobiont present, inhibition of paper birch and jack pine may occur at elevated levels of $\mathrm{Cu}, \mathrm{Ni}$, or $\mathrm{Al}$ in the soil solution (Jones et $a l .$, 1986). Another study demonstrated that survival and growth of pine seedlings significantly improved upon infection with ectomycorrhizal fungi in compromising mine spoils (Marx and Artman, 1979). Pisolithus tinctorius was able to help loblolly and shortleaf pine seedlings to tolerate adverse soil conditions better than Thelephora terrestris even at low nutrient concentrations (Marx and Artman, 1979). Just as soil conditions were not severe enough at Dundee to effect any differences in height and survival of 
trees on the experimental plantations (Zeleznik and Skousen 1996), soil conditions were also not likely severe enough to restrict fungal diversity on the Dundee site.

We found considerable differences in the number of mycorrhizal tips per unit length of root from Dundee and Georgetown. Mycorrhizal colonization on roots from Georgetown approximately doubled the amount of mycorrhizal tips found at Dundee. Earlier studies suggested that heavymetal environments might compromise the mycorrhizal populations (Bell et al, 1988; Dixon, 1988). Dixon (1988) found that high concentrations of cadmium, nickel, and lead reduced ectomycorrhizal colonization of Quercus rubra. Bell et al. (1988) also showed that the frequency of mycorrhizal root tips was reduced in heavy-metal soils compared to non-stressed soils. However, results of Gehring and Whitman (1995) found approximately twofold higher levels of ectomycorrhizal colonization on roots from stressed soils. Another study looking at temporal variation found significantly higher ectomycorrhizal colonization on a stressed site (Swaty et al., 1998). Our findings, however, were consistent with Dixon (1988) and Bell et al. (1988) and suggested that even though diversity restrictions from the availability of heavy-metals were not detected, reduced mycorrhizal colonization in response to heavy-metal stress was detected.

Colonization data from the field roots suggested that roots from the Georgetown site had approximately twice the amount of colonization of those 
from Dundee. However, colonization data from the traps was the opposite. Seedlings planted in soil from Dundee had approximately twice the mycorrhizal root tips compared to those planted in soil from Georgetown. Baxter et al. (1999) found similar results. Their stressed sites had significantly lower colonization in the field and significantly higher colonization in the greenhouse. Our results indicate that optimum conditions in the greenhouse led to more colonization of seedlings.

Visual typing of ectomycorrhizae root morphotype underestimated genotypic diversity. Timonen et al. (1997) also observed different fingerprints of morphotypes that had been visually grouped together. Just as visually typing mycorrhizae underestimated diversity, counting of fruiting bodies also underestimated diversity. During the exceptionally dry years over which this study was conducted (1997-1998), less than 10 sporocarps were found on the two sites together. These results support those of others who rejected the use of sporocarps as ectomycorrhizal fungi diversity indicators (Gehring et al., 1998; Gardes and Bruns, 1996).

We found that 19 (63\%) of the 30 species examined amplified with the primer combination ITS1/ITS4B indicating that they were basidiomycetes. The other 37\% are possibly in the phylum Ascomycota. Gehring et al. (1998) also found that $33 \%$ of examined mycorrhizal tips were not Basidiomycetes.

Clearly different species were abundant on each of the two sites. Our results differ from those of Gehring et al. (1998) who found two 
ectomycorrhizal types dominated on sandy-loam soils. The cinder sites examined by these authors showed very different results than the data for the current study's stressed site. They found each cinder site was dominated by a different fungus (Gehring et al., 1998).

We found that trap cultures growing for 3 months were insufficient indicators of community diversity. One fungus dominated on all trap trees and only one other fungus was detected on one tree. Certain fungi have been considered pioneering fungi that infect young seedlings in the field (Deacon, 1997). Fungi initially colonizing a root system, are thought to be replaced on the roots nearest the trunk by late-colonizing fungal species (Bruns, 1995). No evidence of succession was detected in the trap cultures due to a limited growth period and a limit of seedlings grown to check over the course of the experiment. However, the 'rust brown' fungus isolated from the traps provides a means by which we can investigate intraspecific variation in ectomycorrhizal fungi from divergent soil ty pes. 


\section{REFERENCES}

Allen, E.B., M.F. Allen, D.J. Helm, J.M. Trappe, R. Molina, and E. Rincon. 1995. Patterns and regulation of mycorrhizal plant and fungal diversity. Plant and Soil 170: 47-62.

Annis, S.L. and D.G. Panaccione. 1998. Presence of peptide synthetase gene transcripts and accumulation of ergopeptines in Claviceps purpurea and Neotyphodium coenophialum. Can. J. Microbiol. 44: 80-86.

Barnhisel, R.I. and J.M. Hower. 1997. Coal surface mine reclamation in the eastern United States: The revegetation of disturbed lands to hayland/pasture or cropland. Advances in Agronomy 61: 233-275.

Baxter, J.W., S.T.A. Pickett, M.M. Carreiro, and J. Dighton. 1999. Ectomycorrhizal diversity and community structure in oak forest stands exposed to contrasting anthropogenic impacts. Can. J. Bot. 77: 771-782.

Bell, R., C.S. Evans, and E.R. Roberts. 1988. Decreased incidence of mycorrhizal root tips associated with soil heavy-metal enrichment. Plant and Soil 106: 143-145.

Bills, G.F., G.I. Holtzman, and O.K. Miller, Jr. 1986. Comparison of ectomycorrhizal-Basidiomycete communities in red spruce versus northern hardwood forests of West Virginia. Can. J. Bot. 64: 760-768.

Bradbury, S.M., R.M. Danielson, and S. Visser. 1998. Ectomycorrhizas of regenerating stands of lodgepole pine (Pinus contorta). Can. J. Bot. 76: 218227.

Bruns, T. 1995. Thoughts on the processes that maintain local species diversity of ectomycorrhizal fungi. Plant and Soil 170: 63-73.

Cumming, J. and D. Panaccione. 2000. Personal communication.

Dahlberg, A., L. Jonsson, and J.E. Nylund. 1996. Species diversity and distribution of biomass above and below ground among ectomycorrhizal fungi in an old-growth Norway spruce forest in south Sweden. Can. J. Bot. 75: 1323-1335.

Deacon, J.W. 1997. Fungi as plant parasites. In Modern Mycology. University Press, Cambridge. pp. 246-252. 
Dixon, R.K. 1988. Response of ectomycorrhizal Quercus rubra to soil cadmium, nickel and lead. Soil Biol. Biochem. 20: 555-559.

Gardes, M. and T.D. Bruns. 1996. Community structure of ectomycorrhizal fungi in a Pinus muricata forest: above- and below-ground views. Can. J. Bot. 74: 1572-1583.

Gardes, M. and T.D. Bruns. 1993. ITS primers with enhanced specificity for Basidiomycetes-appication to the identification of mycorrhizae and rusts. Molecular Ecology 2: 113-118.

Gehring, C.A., T.C. Theimer, T.G. Whitham, and P. Keim. 1998. Ectomycorrhizal fungal community structure of pinyon pines growing in two environmental extremes. Ecology 79: 1562-1572.

Gehring, C.A. and T.G. Whitham. 1995. Duration of herbivore removal and environmental stress affect the ectomycorrhizae of Pinyon pines. Ecology 76: 2118-2123.

Gillis, A.M. 1991. Bring back the land: Ecologist evaluate reclamation success on western coal lands. Bioscience 41: 68-71.

Gould, A.B., J.W. Hendrix, and R.S. Ferriss. 1996. Relationship of mycorrhizal activity to time following reclamation of surface mine land in western Kentucky. I. Propagule and spore population densities. Can. J. Bot. 74: 247-261.

Hartley, J., J.W.G. Cairney, and A.A. Meharg. 1997. Do ectomycorrhizal fungi exhibit adaptive tolerance to potentially toxic metals in the environment? Plant and Soil 189: 303-319.

Jones, M.D., M.H.R. Browning, and T.C. Hutchinson. 1986. The influence of mycorrhizal associations on paper birch and jack pine seedlings when exposed to elevated copper, nickel or aluminum. Water, Air, and Soil Pollution 31: 441-448.

Kranabetter, J.M. and T. Wylie. 1998. Ectomycorrhizal community structure across forest openings on naturally regenerated western hemlock seedlings. Can. J. Bot. 76: 189-196.

Lee, J.L. and D.E. Weber. 1979. The effect of simulated acid rain on seedling emergence and growth of eleven woody species. Forest Science 25: 393-398. 
Marx, D.H. 1980. Role of mycorrhizae in forestation of surface mines. In Trees for Reclamation. Interstate Mining Compact Commission and U.S.D.A. Forest Service General, Technical Report NE 61. Lexington, Kentucky. pp. 109-116.

Marx, D.H. and J.D. Artman. 1979. Pisolithus tinctorius ectomycorrhizae improve survival and growth of pine seedlings on acid coal spoils in Kentucky and Virginia. Reclamation Review 2: 23-31.

Marx, D.H. 1969. The influence of ectotrophic mycorrhizal fungi on the resistance of pine roots to pathogenic infections. I. Antagonism of mycorrhizal fungi to root pathogenic fungi and soil bacteria. Phytopathology 59: 153-163.

Skousen, J.G., C.D. Johnson, and K. Garbutt. 1994. Natural revegetation of 15 abandoned mine land sites in West Virginia. J. Environ. Qual. 23: 12241230 .

Swaty, R.L., C.A. Gehring, M. Van Ert, T.C. Theimer, P. Keim, and T.G. Whitham. 1998. Temporal variation in temperature and rainfall differentially affects ectomycorrhizal colonization at two contrasting sites. New Phytol. 139: 733-739.

Timonen, S., H. Tammi, and R. Sen. 1997. Characterization of the host genotype and fungal diversity in Scots pine ectomycorrhiza from natural humus microcosms using isozyme and PCR-RFLP analyses. New Phytol. 135: $313-323$.

White, T.J., T.D. Bruns, S.B. Lee, and J.W. Taylor. 1990. Amplification and direct sequencing of fungal ribosomal RNA genes for phyologenetics. In PCR protocols-a guide to methods and applications. Edited by M.A. Innis, D.H. Gelfand, J.J. Sninsky, and T.J. White. Academic Press, New York. pp. 315322.

Zeleznik, J.D. and J.G. Skousen. 1996. Survival of three tree species on old reclaimed surface mines in Ohio. J. Environ. Qual. 25: 1429-1435. 
Table 1-1. Soil characteristics.

Soil characteristics of reclaimed surface mine sites at Georgetown and Dundee, Ohio ${ }^{1}$.

\begin{tabular}{|l|c|c|}
\hline Parameter & Georgetown $^{2}$ & Dundee \\
\hline pH & 7.7 & 4.2 \\
\hline Calcium (mg/kg) & $431.0(6.2)$ & $36.3(2.9)$ \\
\hline Potassium $(\mathbf{m g} / \mathbf{k g})$ & $4.80(0.12)$ & $2.92(0.10)$ \\
\hline Sodium $(\mathbf{m g} / \mathbf{k g})$ & $0.53(0.04)$ & $0.60(0.04)$ \\
\hline Magnesium $\mathbf{( m g / k g ) ~}$ & $35.3(1.7)$ & $16.4(1.6)$ \\
\hline Al $\mathbf{( m g} / \mathbf{k g})$ & $0.17(0.07)$ & $377.0(42.5)$ \\
\hline Iron $(\mathbf{m g} / \mathbf{k g})$ & $32.9(1.5)$ & $269.0(17.2)$ \\
\hline
\end{tabular}

${ }^{1}$ Soils were extracted with $1 M$ ammonium acetate at $\mathrm{pH} 7.0$ and analyzed by inductively coupled plasma emission spectroscopy (Zeleznik and Skousen, 1996)

2 Mean values with standard errors in parenthesis 
Table 1-2. Morphological categorization of trap culture roots.

Morphological categorization of mycorrhizal tips collected from trap cultures of white pine seedling.

\begin{tabular}{|c|c|c|c|c|}
\hline $\begin{array}{l}\text { Morph } \\
\text { ID }\end{array}$ & Color & Surface & Branching & $\begin{array}{c}\text { Extramatrical } \\
\text { Hyphae }\end{array}$ \\
\hline 1 & $\begin{array}{l}\text { Tip: orange/white } \\
\text { Base: dark brown }\end{array}$ & $\begin{array}{l}\text { Smooth to } \\
\text { semi-wooly }\end{array}$ & $\begin{array}{l}\text { Bifurcate, } \\
\text { doubly } \\
\text { bifurcate }\end{array}$ & Present \\
\hline 2 & $\begin{array}{l}\text { Throughout tip: } \\
\text { peach/orange }\end{array}$ & $\begin{array}{l}\text { Smooth to } \\
\text { semi-wooly }\end{array}$ & $\begin{array}{l}\text { Coralloid, } \\
\text { bifurcate }\end{array}$ & Present \\
\hline 3 & $\begin{array}{l}\text { Tip: white } \\
\text { Base: black }\end{array}$ & $\begin{array}{l}\text { Semi-wooly } \\
\text { to wooly }\end{array}$ & Bifurcate & Present \\
\hline 4 & $\begin{array}{l}\text { Tip: gray/white } \\
\text { Base: light gray/ } \\
\text { black }\end{array}$ & $\begin{array}{l}\text { Smooth to } \\
\text { semi-wooly }\end{array}$ & Bifurcate & Present \\
\hline 5 & $\begin{array}{l}\text { Tip: light } \\
\text { orange/white } \\
\text { Base: burnt red }\end{array}$ & Smooth & Bifurcate & Present \\
\hline 6 & \begin{tabular}{|l} 
Tip: white \\
Base: very light \\
tan/orange
\end{tabular} & $\begin{array}{l}\text { Semi-wooly } \\
\text { to wooly }\end{array}$ & $\begin{array}{l}\text { Bifurcate, } \\
\text { monopodal }\end{array}$ & Present \\
\hline 7 & $\begin{array}{l}\text { Tip: red/orange } \\
\text { Base: black }\end{array}$ & Smooth & Bifurcate & Few \\
\hline 8 & $\begin{array}{l}\text { Tip: whitish } \\
\text { Base: brown/orange }\end{array}$ & Very wooly & Bifurcate & Many \\
\hline 9 & $\begin{array}{l}\text { Tip: white } \\
\text { Base: olive green }\end{array}$ & Semi-wooly & $\begin{array}{l}\text { Bifurcate, } \\
\text { monopodal }\end{array}$ & Present \\
\hline 10 & $\begin{array}{l}\text { Throughout tip: very } \\
\text { white }\end{array}$ & Very wooly & $\begin{array}{l}\text { Bifurcate, } \\
\text { monopodal }\end{array}$ & Very many \\
\hline
\end{tabular}


Table 1-3. Morphological categorization of field roots.

Morphological categorization of mycorrhizal tips collected from white pine tree roots at Dundee and Georgetown, Ohio.

\begin{tabular}{|l|l|l|l|l|}
\hline $\begin{array}{c}\text { Morph } \\
\text { ID }\end{array}$ & \multicolumn{1}{|c|}{ Color } & \multicolumn{1}{|c|}{ Surface } & Branching & $\begin{array}{l}\text { Extramatrical } \\
\text { Hyphae }\end{array}$ \\
\hline F1 & Orange & Smooth & $\begin{array}{l}\text { Coralloid, } \\
\text { bifurcate }\end{array}$ & Present \\
\hline F2 & Light peach/yellow & $\begin{array}{l}\text { Covered with } \\
\text { hyphae }\end{array}$ & $\begin{array}{l}\text { Coralloid, } \\
\text { bifurcate }\end{array}$ & $\begin{array}{l}\text { Present, snow } \\
\text { white }\end{array}$ \\
\hline F3 & Black & Smooth & Bifurcate & Very few \\
\hline F4 & Orange & $\begin{array}{l}\text { Covered with } \\
\text { hyphae, but not } \\
\text { wooly }\end{array}$ & $\begin{array}{l}\text { Monopodal } \\
\text { bifurcate }\end{array}$ & $\begin{array}{l}\text { Present, Very } \\
\text { yellow and } \\
\text { large amount }\end{array}$ \\
\hline F5 & Burnt red & Smooth & Coralloid & Few \\
\hline F6 & Orange/brown & Very wooly & $\begin{array}{l}\text { Monopodal } \\
\text { bifurcate }\end{array}$ & $\begin{array}{l}\text { Present, golden, } \\
\text { but very wooly }\end{array}$ \\
\hline F7 & Yellow/white/mauve & Wooly & Bifurcate & $\begin{array}{l}\text { Present, long, } \\
\text { translucent }\end{array}$ \\
\hline F8 & Red/brown to brown & $\begin{array}{l}\text { Smooth, hyphae } \\
\text { covers surface }\end{array}$ & Bifurcate & $\begin{array}{l}\text { Present, brown, } \\
\text { but not wooly }\end{array}$ \\
\hline F9 & Deep purple & Smooth & Bifurcate & Few \\
\hline F10 & Yellow/orange/white & $\begin{array}{l}\text { Smooth, hyphae } \\
\text { covers surface }\end{array}$ & Bifurcate & $\begin{array}{l}\text { Present, white, } \\
\text { not wooly }\end{array}$ \\
\hline F11 & Brown/red & Smooth & Bifurcate & Few \\
\hline F12 & Light pink/orange & $\begin{array}{l}\text { Smooth, hyphae } \\
\text { covers surface }\end{array}$ & Bifurcate & $\begin{array}{l}\text { Present, } \\
\text { pink/white }\end{array}$ \\
\hline F13 & Gray & Smooth & Bifurcate & Few \\
\hline F14 & Black & Very wooly & Bifurcate & $\begin{array}{l}\text { Present, very } \\
\text { black }\end{array}$ \\
\hline
\end{tabular}




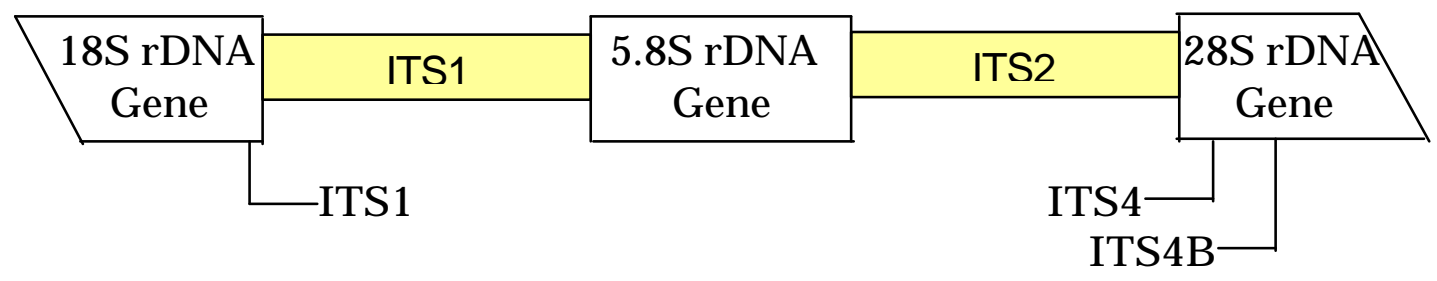

Figure 1-1. Diagram of the ITS region.

Structure of the ITS region in fungal DNA (adapted from Gardes and Bruns, 1993). Shows orientation and approximate location of primers for PCR amplification. Sequences of the ITS1, ITS4, and ITS4B primers:

ITS1 (5'-TCCGTAGGTGAACCTGCGG-3') ITS4 (5'-TCCTCCGCTATTGATATGC-3') ITS4B (5'-CAGGAGACTTGTACACGGTCCAG-3') 

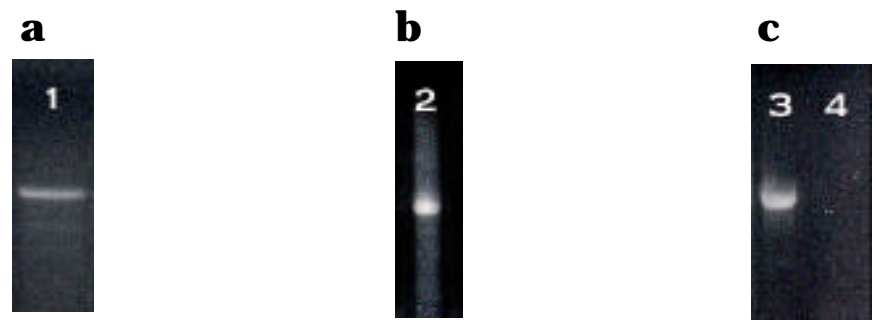

Figure 1-2. Amplification products of the ITS region.

Amplification products from the ITS regions of Basidiomycete and nonBasidiomycete fungi. Lanes 1 and 3 contain products amplified from isolate A439 template rDNA. Isolate A423 DNA was template for amplification products in lanes 2 and 4. Primer combinations in PCR were: a) ITS1/ITS4; b) ITS1/ITS4; and, c) ITS1/ITS4B. Products were electrophoresed through $1.5 \%$ agarose. 
Figure 3: Morphotypes from Trap Cultures
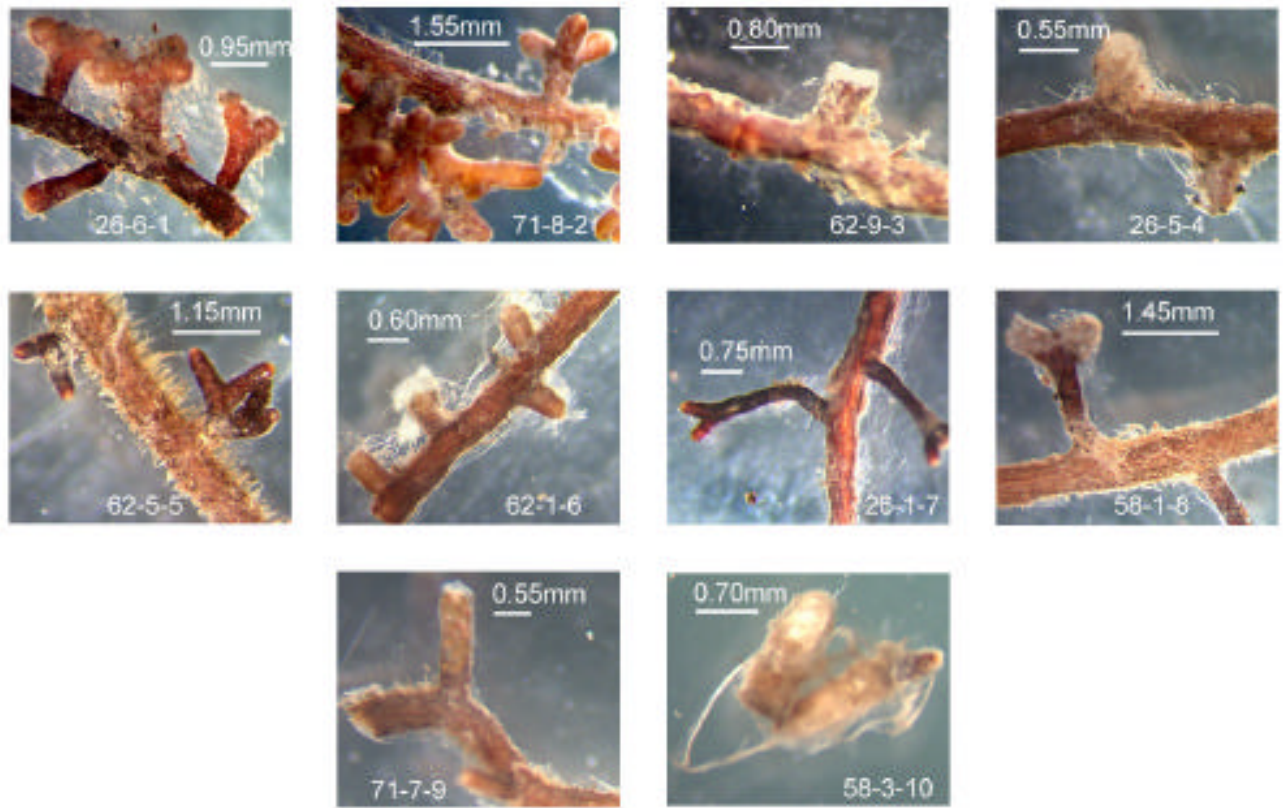

Figure 4: Morphotypes from Field Collection
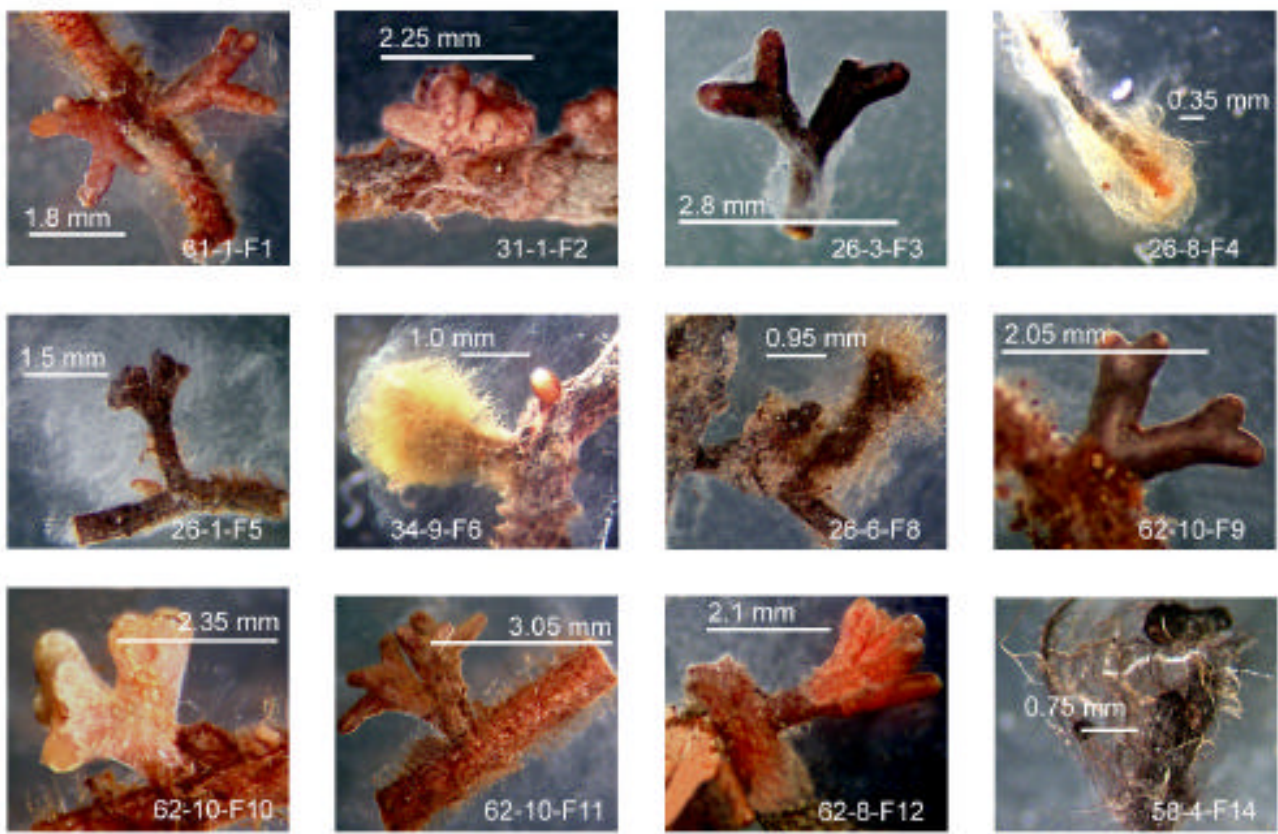
Figure 1-3. Morphotypes from trap cultures.

Comparison of mycorrhizal root tip morphotypes on white pine seedlings grown in pot cultures for 3 months containing representative morphotypes were photographed under a dissecting microscope. All were photographed in water under an Olympus stereomicroscope. The first number represents the plot in which the mycorrhizal tip was found (26, 31, 34 for Georgetown; 58, 62, 71 for Dundee). The middle number represents the tree number in which the isolates were found. Finally, the last number represents the root morphotype. Please see Table 1-2.

Figure 1-4. Morphotypes from field collection.

Comparison of mycorrhizal root tip morphotypes from field roots of white pine. Roots collected from trees in the field were photographed under a dissecting microscope. All were photographed in water under an Olympus stereomicroscope. Root numbering system is described in the legend to Figure 1-7. Please see Table 1-3. 
$\mathbf{a}$

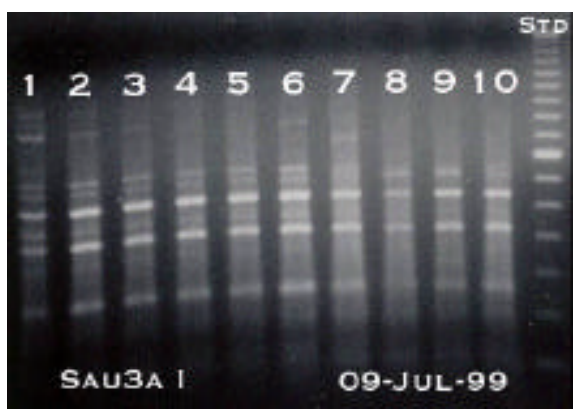

b

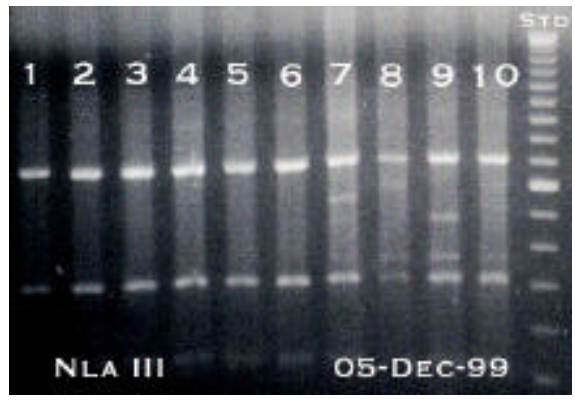

Figure 1-5. RFLP analysis of the F12 morphotype.

RFLP analysis of the F12 morphotype with the enzymes Sau 3AI and Nla III. The PCR products of the F12 morphotype amplified with ITS1/ITS4 primer combination were digested with Sau 3AI (a) and Nla III (b). Lane 1 = A146, lane $2=\mathrm{A} 147$, lane $3=\mathrm{A} 148$, lane $4=\mathrm{A} 149$, lane $5=\mathrm{A} 150$, lane $6=\mathrm{A} 152$, lane $7=\mathrm{A} 151$, lane $8=\mathrm{A} 154$, lane $9=$ A156, lane $10=\mathrm{A} 157$, and $\mathrm{Std}=50$ base pair ladder from GIBCO BRL. 
$\mathbf{a}$

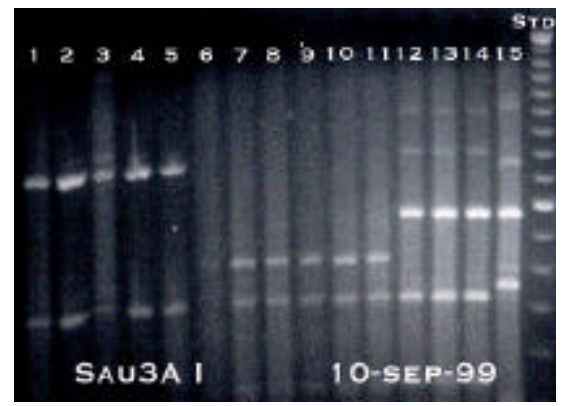

b

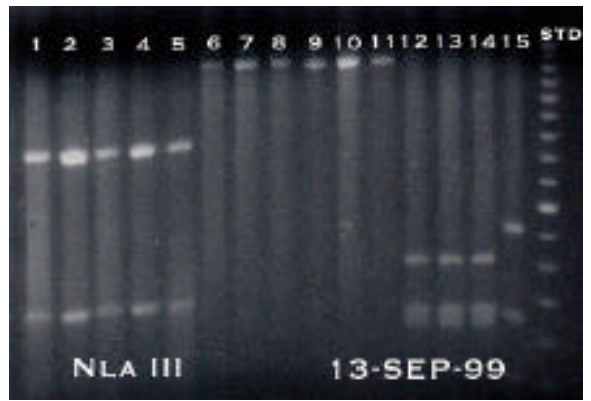

Figure 1-6. RFLP analysis of the F10 morphotype.

RFLP analysis of the F10 morphotype with the enzyme Sau 3AI and Nla III. The PCR products of the F10 morphotype amplified with ITS1/ITS4 primer combination were digested with Sau 3AI (a) and Nla III (b). Lane $1=\mathrm{A} 273$, lane $2=\mathrm{A} 274$, lane $3=\mathrm{A} 275$, lane $4=\mathrm{A} 276$, lane $5=\mathrm{A} 277$, lane $6=\mathrm{A} 278$, lane $7=\mathrm{A} 279$, lane 8 $=\mathrm{A} 280$, lane $9=\mathrm{A} 281$, lane $10=\mathrm{A} 282$, lane $11=\mathrm{A} 283$, lane $12=$ $\mathrm{A} 284$, lane $13=\mathrm{A} 285$, lane $14=\mathrm{A} 286$, lane $15=\mathrm{A} 287$, and Std $=$ 50 base pair ladder from GIBCO BRL. 
Table 1-4. Distribution of fungal species

Distribution of fungal species found on alkaline site Georgetown (plots 26, 31 , and 34), and the acidic site Dundee (plots 58, 62, and 71), based on RFLP patterns. Isolates initially were differentiated (F1 - F14) by morphological criteria (Table 1-3).

\begin{tabular}{|c|c|c|c|c|c|c|}
\hline $\begin{array}{l}\text { Fungal } \\
\text { Species }\end{array}$ & Plot 26 & Plot 31 & Plot 34 & Plot 58 & Plot 62 & Plot 71 \\
\hline F1A & & $\mathrm{X}$ & $\mathrm{X}$ & & & \\
\hline F1B & $\mathrm{X}$ & $\mathrm{X}$ & & & & \\
\hline F1C & & & & & $\mathrm{X}$ & \\
\hline F1D & & & & & & $\mathrm{X}$ \\
\hline F1E & & & & & $\mathrm{X}$ & \\
\hline F1F & & & & & & $\mathrm{X}$ \\
\hline F1G & & & $\mathrm{X}$ & & & \\
\hline F1H & $\mathrm{X}$ & & & & & \\
\hline F1I & $\mathrm{X}$ & & & & & \\
\hline F1J & & & & $\mathrm{X}$ & & \\
\hline F1K & $\mathrm{X}$ & & & & & \\
\hline F2 & $\mathrm{X}$ & $\mathrm{X}$ & $\mathrm{X}$ & & & \\
\hline F3A & $\mathrm{X}$ & $\mathrm{X}$ & $\mathrm{X}$ & & & \\
\hline F3B & & & $\mathrm{X}$ & & & \\
\hline F3C & & $\mathrm{X}$ & & & & \\
\hline F4 & $\mathrm{X}$ & & & & & \\
\hline F6 & $\mathrm{X}$ & & & & & \\
\hline F7A & $\mathrm{X}$ & & & & & \\
\hline F7B & & & $\mathrm{X}$ & & & \\
\hline F7C & & & & $\mathrm{X}$ & & \\
\hline F8 & $\mathrm{X}$ & & & & & \\
\hline F9A & & & & & $\mathrm{X}$ & \\
\hline F9B & & & & & & $\mathrm{X}$ \\
\hline $\begin{array}{l}\text { F10A } \\
\end{array}$ & & & & $\mathrm{X}$ & & $\mathrm{X}$ \\
\hline F10B & & & & & $\mathrm{X}$ & \\
\hline F10C & & & & & $\mathrm{X}$ & \\
\hline F10D & & & & & & $\mathrm{X}$ \\
\hline F10E & & & & & & $\mathrm{X}$ \\
\hline F11 & & & & $\mathrm{X}$ & $\mathrm{X}$ & \\
\hline F12 & & & & $\mathrm{X}$ & $\mathrm{X}$ & $\mathrm{X}$ \\
\hline $\begin{array}{l}\text { Cenococcum } \\
\text { geophilum }\end{array}$ & & & & $\mathrm{X}$ & & \\
\hline $\begin{array}{l}\text { Species } \\
\text { Richness on } \\
\text { Plots }\end{array}$ & 10 & 5 & 6 & 6 & 7 & 7 \\
\hline $\begin{array}{l}\text { Species } \\
\text { Richness on } \\
\text { Sites }\end{array}$ & \multicolumn{3}{|c|}{$\begin{array}{l}\text { Georgetown } \\
15\end{array}$} & \multicolumn{3}{|l|}{$\begin{array}{l}\text { Dundee } \\
16\end{array}$} \\
\hline
\end{tabular}


Figure 1-7. Basidiomycete and non-Basidiomycete percentages.

Thirty species were examined by PCR for amplification with ITS1/ITS4B.

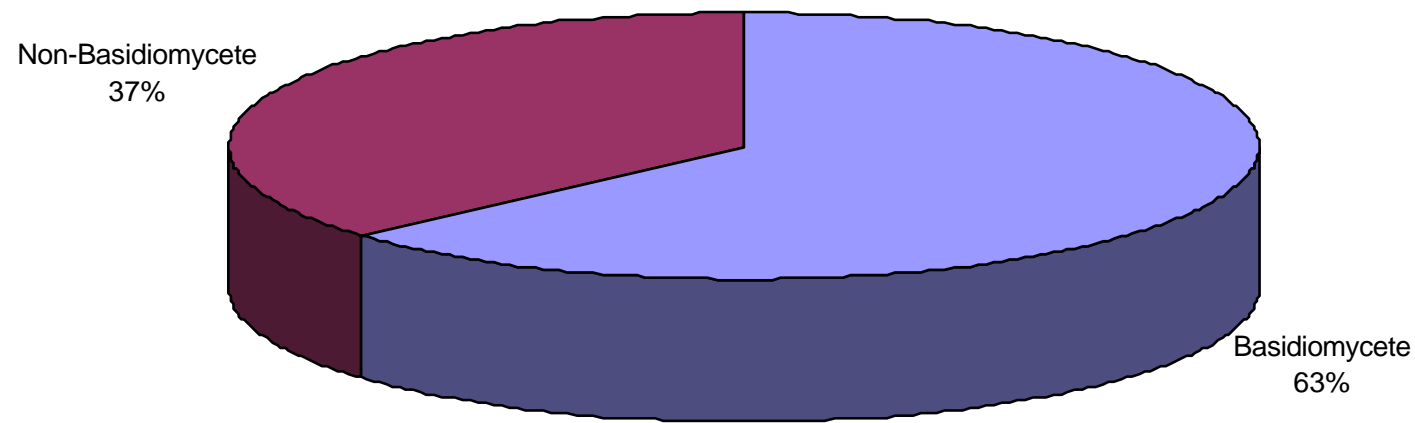


Table 1-5. Distribution of Basidiomycetes.

Distribution of Basidiomycetes by plot in the two sites sampled (Georgetown and Dundee, Ohio).

\begin{tabular}{|l|l|l|l|l|l|l|}
\hline & Plot 26 & Plot 31 & Plot 34 & Plot 58 & Plot 62 & Plot 71 \\
\hline Basidiomycete & 7 & 3 & 3 & 2 & 5 & 7 \\
\hline $\begin{array}{l}\text { Non- } \\
\text { Basidiomycete }\end{array}$ & 2 & 2 & 3 & 3 & 2 & 0 \\
\hline Not checked & 1 & 0 & 0 & 0 & 0 & 0 \\
\hline & \multicolumn{3}{|c|}{ Georgetown Totals } & \multicolumn{2}{|c|}{ Dundee Totals } \\
\hline & \multicolumn{3}{|c|}{} & \multicolumn{3}{|c|}{11} \\
Basidiomycete & \multicolumn{3}{|c|}{6} & \multicolumn{3}{|c|}{5} \\
\hline $\begin{array}{l}\text { Non- } \\
\text { Basidiomycete }\end{array}$ & \multicolumn{3}{|c|}{1} & \multicolumn{3}{|c|}{0} \\
\hline Not checked & \multicolumn{3}{|c|}{1} & & & \\
\hline
\end{tabular}


Table 1-6. Comparison of community diversity.

Comparison of community diversity of ectomycorrhizal funi isolated from white pine trees at Georgetown and Dundee, Ohio. Species were defined by discrete differences in RFLP banding patterns of PCR amplified ITS regions in rDNA.

\begin{tabular}{|c|c|c|c|}
\hline Georgetown & $\begin{array}{l}\text { Shannon- } \\
\text { Weiner Index }\end{array}$ & $\begin{array}{l}\text { Species } \\
\text { Richness }\end{array}$ & $\begin{array}{l}\text { Species } \\
\text { Evenness }\end{array}$ \\
\hline 26 & 0.969 & 10 & 0.969 \\
\hline 31 & 0.587 & 5 & 0.840 \\
\hline 34 & 0.699 & 6 & 0.898 \\
\hline Mean & 0.752 & 7 & 0.902 \\
\hline $\begin{array}{c}\text { Population } \\
\text { Variance }\end{array}$ & 0.023 & 4.67 & 0.003 \\
\hline $\begin{array}{c}\text { Standard } \\
\text { Deviation }\end{array}$ & 0.152 & 2.16 & 0.055 \\
\hline Dundee & $\begin{array}{c}\text { Shannon- } \\
\text { Weiner Index }\end{array}$ & $\begin{array}{l}\text { Species } \\
\text { Richness }\end{array}$ & $\begin{array}{c}\text { Species } \\
\text { Evenness }\end{array}$ \\
\hline 58 & 0.71 & 6 & 0.912 \\
\hline 62 & 0.779 & 7 & 0.922 \\
\hline 71 & 0.77 & 7 & 0.911 \\
\hline Mean & 0.753 & 6.67 & 0.915 \\
\hline $\begin{array}{c}\text { Population } \\
\text { Variance }\end{array}$ & 0.001 & 0.233 & 0.00003 \\
\hline $\begin{array}{c}\text { Standard } \\
\text { Deviation }\end{array}$ & 0.032 & 0.483 & 0.005 \\
\hline $\begin{array}{l}\text { t Values for } \\
\text { Georgetown } \\
\text { and Dundee }\end{array}$ & $\begin{array}{c}\mathrm{t}_{0.05,4}=2.132> \\
0.0111\end{array}$ & $\begin{array}{c}\mathrm{t}_{0.05,4}=2.132> \\
0.258\end{array}$ & $\begin{array}{c}\mathrm{t}_{0.05,4}=2.132 \\
>0.351\end{array}$ \\
\hline
\end{tabular}


$\mathbf{a}$

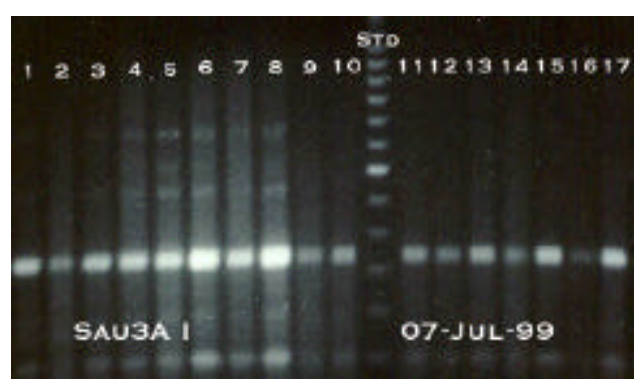

b

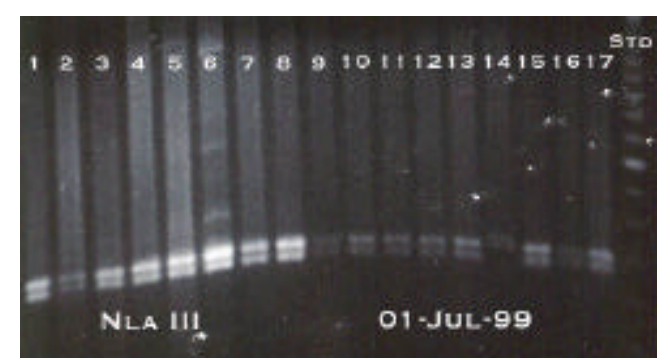

Figure 1-8. RFLP analysis of the 'rust brown' isolates

RFLP analysis of the 'rust brown' isolates with the enzyme Sau

3AI and Nla III. The 'rust brown' fungal isolates obtained from the trap cultures were amplified with the primer combination ITS1/ITS4 then digested with Sau 3AI (a) and Nla III (b). Lane 1

$=26-2-1$, lane $2=34-2-1$, lane $3=34-10-2$, lane $4=26-6-2$, lane 5 $=58-1-2$, lane $6=58-4-1$, lane $7=62-1-2$, lane $8=62-10-2$, lane 9 $=31-2-2$, lane $10=34-8-7$, lane $11=62-7-9$, lane $12=71-8-2$, lane $13=31-5-5$, lane $14=31-1-2$, lane $15=71-10-2$, lane $16=58-8-2$, lane 17 = root sample $26-5-2$ and $S t d=50$ base pair ladder from GIBCO BRL. 


\section{CHAPTER 2}

Genotypic and physiological analyses of populations of Wilcoxina mikolae isolated from acidic and alkaline coal mine soils. 


\section{INTRODUCTION}

One of the primary factors affecting the reclamation of mine lands is the composition of the overburden. When exposed to oxygen and water, pyritic material contained in the overburden oxidizes to produce sulfuric acid (Evangelou et al., 1985). The sulfuric acid produced by pyrite weathering decreases the $\mathrm{pH}$ of the soil (Chichester and Hauser, 1991) and leads to increased metal availability in the soil (Zel et al., 1993). Many metals, including aluminum (Al), iron ( $\mathrm{Fe})$, and manganese ( $\mathrm{Mn})$, exhibit $\mathrm{pH}$ dependant solubility. As soil $\mathrm{pH}$ drops, the concentration of these metals increases, leading to phytotoxicity. A soil $\mathrm{pH}$ of 4.5 is considered an optimum level for aluminum toxicity to plants (Grauer, 1992). When $\mathrm{pH}$ values of the soil solution are near neutral, concentrations of $\mathrm{Fe}^{n+}, \mathrm{Al}^{n+}, \mathrm{Mn}^{2+}$, and $\mathrm{Zn}^{2+}$ are very low (Wilden et al., 1999).

Studies indicate that species of mycorrhizal fungi, and perhaps isolates within species, vary in Al tolerance. Cumming and Weinstein (1990) showed that Pisolithus tinctorius was able to protect seedlings from adverse $\mathrm{Al}$ affects. Cumming et al. (unpublished) found that Laccaria bicolor and $P$. tinctorius tolerated $\mathrm{Al}$ concentrations up to $500 \mu \mathrm{M}$ in vitro. Thomson and Medve (1984) saw significant growth reduction in response to $\mathrm{Al}$ from Suillus luteus, P. tinctorius, Cenococcum graniforme, and Thelephora terrestris. Jongbloed and Borst-Pauwels (1992) found Lactarius rufus and Lactarius hepaticus to be more $\mathrm{Al}$ sensitive than Laccaria bicolor. However, Jongbloed 
et al. (1992) saw a reduction in phosphate uptake in the presence of $\mathrm{Al}$ by all three fungi L. rufus, L. hepaticus, and L. bicolor.

As previously described in chapter 1 , trap cultures did not provide a complete representation of fungal diversity of Georgetown and Dundee. However, sixteen isolates of a fungus provisionally called 'rust brown' were cultured successfully. RFLP patterns of 'rust brown' isolates digested with Sau 3A I and Nla III established that they were from the same species. In this chapter we classify the 'rust brown' isolate and determine if it can recolonize Pinus strobus seedlings and form similar ectomycorrhizae. We investigate the genetic relationships among the 16 isolates, some of which originated from alkaline soil at Georgetown and others from acidic soil at Dundee. We hypothesized that intraspecific variation is likely between sites, but variation would be minimal within sites. Finally, we examine the affects of subjecting all isolates to different $\mathrm{Al}$ concentrations and $\mathrm{pH}$ ranges. Considering differences in environment between the Georgetown and Dundee soil (Zeleznik and Skousen, 1996) (Table 1; Chapter 1), we hypothesized that fungal isolates from Georgetown (alkaline) would produce greater dry weight in treatments with no $\mathrm{Al}$ and higher $\mathrm{pH}$. We also hypothesized that the Dundee (acidic) site isolates would produce greater dry weight than the Georgetown sites when exposed to low $\mathrm{pH}$ and high $\mathrm{Al}$. 


\section{MATERIALS AND METHODS}

\section{DNA Sequence Analysis of 'Rust Brown' Isolate:}

The ITS region of the 'rust brown' isolate (isolate 31-2-2) was amplified from primers ITS-1X (5'TATCTAGATCCGTAGGTGAACCTGCGG-3') and ITS-4X (5'-TCTCTAGATCCTCCGCTTATTGATATGC-3'). These are essentially primers ITS1 and ITS4 (White et al., 1990) with additional nucleotides at the 5' ends to create $X b a$ I sites. Amplification conditions were the same as those described in Chapter 1. PCR products were digested with $X b a$ I and ligated into the $X b a$ I site of pBluescript (Stratagene, San Diego, CA). The ligation mixture was transformed into Escherichia coli strain $\mathrm{DH} 5 \propto$ by the $\mathrm{CaCl}_{2}$ method (Sambrook et al., 1989). The insert (both strands) of the recombinant plasmid was sequenced by the Michigan State University DNA Sequencing Facility. Sequence data were compared (with and without the 5.8s coding sequences) to GenBank and EMBL databases with the blastn algorithm (www.ncbi.nlm.nih.gov/).

\section{Koch's Postulates:}

To confirm that the 'rust brown' isolates were ectomycorrhizal, 7 sterile Pinus strobus seedlings (Chapter 1) were inoculated with 'rust brown' cultures (isolate 31-2-2). Seedlings were planted in sterile sand in 500-ml flasks containing Modified Melin-Norkans (MMN) media (Molina and Palmer, 1982), inoculated with mycelial plugs from axenic culture, and grown 
for 3 months. Roots were examined under a dissecting microscope and mycorrhizal tips excised. DNA was extracted from mycorrhizal tips with GeneClean Spin Kit (Bio101, Vista, CA) and the ITS regions were amplified by PCR. The second generation mycorrhizal tips were compared to the first generation root tips by digesting the PCR products with Sau 3AI and Nla III (New England Bio Labs, Beverly, MA).

\section{Amplified Fragment Length Polymorphism (AFLP) Analysis:}

Fungal DNA was extracted from 16 'rust brown' isolates with GeneClean Spin Kit (Bio101, Vista, CA) protocol described in Chapter 1. DNA extracts were subjected to restriction, ligation, and amplification as described in GibcoBRL (Gaithersburg, MD) protocols for AFLP Core Reagent Kit using the EcoRI-adapter and the MseI-adapter. Primer pairs E-AC + M$\mathrm{A}, \mathrm{E}-\mathrm{AA}+\mathrm{M}-\mathrm{C}, \mathrm{E}-\mathrm{AA}+\mathrm{M}-\mathrm{A}$, and E-AA + M-G (AFLPTM Microorganism Primer Kit, GibcoBRL, Gaithersburg, MD) were used for amplification of fungal DNA.

Five $\mu \mathrm{l}$ of amplification product and loading dye was loaded onto a $6 \%$ polyacrylamide denaturing gel (Sambrook et al., 1989). Electrophoresis was performed for fragment separation. Amplification products then were electrophoretically transferred to Magnagraph nylon (MSI, Westboro, MA) and then detected using a GibcoBRL AFLP non-radioactive probe. 
Polymorphic fragments were treated as individual characters and scored with a ' 1 ' for present or a ' 0 ' for absent. Distance between isolates in all possible pairwise combinations was calculated according to the formula

$$
\mathrm{S}=2 * \mathrm{n}_{\mathrm{ab}} /\left(\mathrm{n}_{\mathrm{a}}+\mathrm{n}_{\mathrm{b}}\right)
$$

where $\mathrm{n}_{\mathrm{ab}}$ is the total number of bands shared between the two lanes, $\mathrm{n}_{\mathrm{a}}$ is

the number of bands in lane ' $a$ ', and $\mathrm{n}_{\mathrm{b}}$ is the total number of bands in lane ' $\mathrm{b}$ ' (Weising et al., 1995). The relationships among the isolates based on this distance matrix were analyzed with the UPGMA (Unweighted Pair Group Maximum Averages) algorithm of the Phylogeny Inference Package (PHYLIP) (Felsenstein, 1993).

\section{Physiological Study:}

The 16 isolates used in the AFLP study were examined for their response to different $\mathrm{pH}$ and aluminum concentrations in vitro. Treatments for $\mathrm{pH}$ were 4,6 , and 8 with 4 replications for each fungal culture. Treatments for $\mathrm{Al}$ were $0 \mu \mathrm{M}, 100 \mu \mathrm{M}$, and $500 \mu \mathrm{M}$ at $\mathrm{pH} 4$ with four replicates of each fungal culture.

Media preparation:

Modified Melin-Norkans (MMN) (Marks, 1969) was the basal medium used for both the $\mathrm{pH}$ and $\mathrm{Al}$ in vitro experiments. The media for the $\mathrm{pH}$ experiment were buffered with citric acid at the desired $\mathrm{pH}(4,6$, or 8$)$ before filter sterilization and the final $\mathrm{pH}$ averaged $3.88,5.5$, and 6.37 , respectively. All media for the $\mathrm{Al}$ experiment were buffered with fumaric acid at $\mathrm{pH} 4$ to 
maintain $\mathrm{Al}$ availability. Media were filter-sterilized and distributed $40 \mathrm{ml}$ per 125-ml flask.

Inoculation:

Thirteen 6 -mm diameter plugs were cut from each of the 16 plate cultures and then leached in sterile distilled water for 24 hours prior to inoculation. One fungal plug was used to inoculate each treatment. Cultures were incubated at $20^{\circ} \mathrm{C}$ in darkness for 8 weeks.

Harvest:

Filter paper was initially weighed to calculate residual water. Fungal cultures were vacuum-filtered onto pre-weighed filter papers with a Buchner funnel and rinsed with $40 \mathrm{ml}$ of distilled water. The filtered mycelia were dried at $60^{\circ} \mathrm{C}$ for 5 days then weighed.

Statistics:

In vitro growth data were analyzed as nested factorial designs, with isolates nested within sites crossed with media $\mathrm{pH}$ or $\mathrm{Al}$ treatment. Analyses were undertaken in the statistical package JMP (SAS Institute, Carey, NC). Mean separations where undertaken by single degree-of-freedom contrasts.

\section{RESULTS}

\section{Identity of 'Rust Brown' Fungus:}

The DNA sequence of the ITS region of the 'rust brown' fungus was compared to all sequences in the GenBank and EMBL databases by the blastn algorithim. The closest matches were to the ITS region of Wilcoxina 
mikolae (accession numbers U38563 and U38626), a mycorrhizal ascomycete. DNA sequence from the ITS region of the 'rust brown' fungus was compared to the analogous region of other W. mikolae isolates and closely related fungi by the multiple alignment algorithm in DNAsis for Windows version 2.1 (Hitachi Software Engineering Co., San Bruno, CA). The ITS region of our isolate was on average $98.9 \%$ identical to the W. mikolae accessions within GenBank and 99.4\% identical to accession numbers U38563 and U38626 (Fig. 2-1). These data strongly suggest that the 'rust brown' isolate found in our trap culture is W. mikolae.

Pinus strobus seedlings were successfully re-colonized by W. mikoae and formed mycorrhizae morphologically identical to those of trap culture plants (Fig. 1-3 in chapter 1). The identity of the original isolate and the fungus in the synthesized mycorrhizae was demonstrated by ITS/RFLP (Fig. $2-2)$.

\section{AFLP Analysis of W. mikolae Isolates from Acidic and Alkaline Sites:}

Four AFLP primer pairs (E-AC + M-A, E-AA + M-C, E-AA + M-A, and E-AA + M-G) generated 204 polymorphic fragments. The relationship among the 16 isolates of W. mikolae based on the number of shared AFLP fragments is graphically represented by the phonogram produced by the UPGMA algorithm of PHYLIP (Fig. 2-3). Most isolates from both alkaline and acidic sites exhibited only small differences in AFLP patterns, ranging from $1 \%$ to $15 \%$. The most genetically distant isolate, $62-7-9$, originated from the acidic 
site at Dundee. It differed by $31 \%-48 \%$ from other isolates. Dundee isolates 71-8-2 and 71-10-2 differed from other isolates by $25 \%$ to $35 \%$; however, the difference between the two isolates was only $3 \%$. The Georgetown isolate $26-$ 2-1 was also different from other isolates by $29 \%-33 \%$ (Fig. 2-3).

\section{Physiological Analyses:}

W. mikolae isolates grew best at near-neutral $\mathrm{pH}$ in vitro (Fig. 2-4), with growth being reduced by $44 \%$ at $\mathrm{pH} 4$ compared to that at $\mathrm{pH} 6$. Growth responses of Dundee and Georgetown populations did not differ significantly in response to medium $\mathrm{pH}(\mathrm{P}=0.4337)$. Variation was high, however, within populations in response to medium $\mathrm{pH}(\mathrm{P}<0.001)$. Only one isolate, $71-10-2$ from the acidic Dundee site, grew better at $\mathrm{pH} 4$ than at $\mathrm{pH} 6(118 \%$ the mass accumulated at $\mathrm{pH}$ 6). This isolate also was genetically distant from other isolates. Its sister isolate, 71-8-2, also grew well at $\mathrm{pH} 4$, accumulating $79 \%$ of the mass at the lower $\mathrm{pH}$ than the higher $\mathrm{pH}$. However, the remaining Dundee isolates grown at $\mathrm{pH} 4$ accumulated only $38 \%$ the mass compared to that at $\mathrm{pH} 6$. Georgetown isolates grown at $\mathrm{pH} 4$ also accumulated only $38 \%$ the mass at $\mathrm{pH} 6$.

At $\mathrm{pH} 4$, the growth of $W$. mikolae isolates was slightly stimulated by $100 \mu \mathrm{M} \mathrm{Al}$, but was reduced by $16 \%$ at $500 \mu \mathrm{M} \mathrm{Al}$ (Fig. 2-5). Populations responded differentially to $\mathrm{Al}$ concentrations. Whereas Dundee isolates grew equally well at 0 and $100 \mu \mathrm{M} \mathrm{Al}$, growth of the Georgetown isolates was stimulated at $100 \mu \mathrm{M} \mathrm{Al}$ (Fig. 2-5). Growth of isolates from each population 
was highly variable in response to $\mathrm{Al}$, indicating that populations did not segregate consistently under $\mathrm{Al}$ stress $(\mathrm{P}<0.001$ for the $\mathrm{Al}$-by-isolate within site interaction). Analysis of covariance of the $\mathrm{Al}$ treatments indicated that cultures at $\mathrm{pH} 6$ grew better than isolates at $\mathrm{pH} 4$.

\section{DISCUSSION}

The 'rust brown' fungus trapped from reclaimed surface mines was identified as Wilcoxina mikolae. The ITS region of the 'rust brown' isolate was $99.4 \%$ identical to the analogous regions of Wilcoxina mikolae accession numbers U38563 and U38626. Overall, there was 98.9\% identity among in the ITS regions of other W. mikolae isolates (Fig. 2-1). The re-colonization of white pine (Pinus strobus) from the 'rust brown' isolate confirmed that our W. mikolae isolates were mycorrhizal.

Also known as ectendomycorrhizae or E-strain mycorrhizal fungi, $W$. mikolae belongs to the phylum Ascomycota in the order Pezizales (Danielson, 1982). E-strain fungi were originally described as Tricharina mikolae (Yang and Wilcox, 1984). Later, Yang and Korf (1985) placed the E-strain fungi into a new genus, Wilcoxina. Characteristically, the mantle is thin and, depending on the associated host, the Hartig-net hyphae may or may not penetrate the root cortical cells (Scales and Peterson, 1991a and 1991b). Because the root cortical cells may or may not be penetrated, Scales and Peterson (1991b) viewed the 'ectendomycorrhizae' (E-strain) as a variation in 
development of ectomycorrhizae and hypothesized that ectendomycorrhizal fungi were a lineage within the ectomycorrhizal fungi.

Wilcoxina spp. have high affinities to be mycorrhizal in nursery stock and greenhouses (Egger, 1996; Scales and Peterson, 1991a). Danielson and Visser (1990) looked at container-grown trees and shrubs and described Wilcoxina sp. as the primary colonizer of lodgepole pine and white spruce. We found our trap cultures produced W. mikolae on all of our seedlings and only one other species on one tree. This is consistent with the data of Shishido et al. (1996) who detected primarily Wilcoxina sp. on their forestsoil-treated seedlings. Due to the differences between the communities in our field roots and trap roots (Chapter 1), we conclude that trap culture conditions enriched for W. mikolae.

Wilcoxina mikolae is commonly associated with host plants on disturbed soils, including coal mine spoils (Egger, 1996; Yang and Korf, 1985). Furthermore, W. mikolae is adapted to a wide ecological range (Chakravarty et al., 1990) and has the ability to tolerate adverse soil conditions created by disturbance (Egger et al., 1991). Baar et al. (1999) found W. mikolae had colonized seedlings after a forest fire even though prefire data did not detect the fungus. Even though we were unable to detect $W$. mikolae in our field sampling, we were able to trap the fungus on seedlings (Baar et al., 1999). 
AFLP is a sensitive and reliable method for defining differences in populations. Sanchez et al. (1999) found that AFLP revealed genetic similarity of cassava. Panaccione et al. (in review) used AFLP to analyze 18 isolates of Cenococcum geophilum found on serpentine (high concentration of $\mathrm{Mg}^{2+}$ and $\mathrm{Ni}^{2+}$ ) soils and non-serpentine sites. Their data indicated that the serpentine isolates and the non-serpentine isolates were genetically distinct. Another study compared AFLP to RAPD, finding that AFLP showed more genetic diversity than RAPD and that AFLP results were more reproducible (Barker et al., 1999).

Our AFLP study suggested the majority of the isolates of W. mikolae were genetically similar and did not suggest any population specialization based upon soil type or geography. However, several W. mikolae isolates were genetically dissimilar. W. mikolae is a sexually outcrossing species (Yang and Wilcox, 1984) which should result in distribution of AFLP markers among localized compatible isolates. The few genetically dissimilar isolates that we observed may have lost their ability to cross with other individuals on the sites. Different species of Wilcoxina also can cross to form hybrid varieties. Egger et al. (1991) suggested that hybridization occurred between W. mikolae and W. rehmii creating a new variety, W. mikolae var. tetraspora. Hybridization of crossing species could account for the unusual isolates found in our AFLP study. 
Physiological responses of W. mikolae isolates to $\mathrm{Al}$ and $\mathrm{pH}$ were investigated and no significant difference between the two populations was detected in response to these stresses. Across both populations of W. mikolae, $\mathrm{Al}$ stimulated growth at $100 \mu \mathrm{M}$ and significantly reduced growth at $500 \mu \mathrm{M}$. However, the effect of $\mathrm{Al}$ on growth depended on the population. The significant Al-by-population interaction was the result of the stimulation of growth in Georgetown isolates by $100 \mu \mathrm{M} \mathrm{Al}$ compared to controls, whereas growth of isolates from Dundee was unaffected by $100 \mu \mathrm{M}$ Al. The growth of isolates from both populations was similarly reduced at $500 \mu \mathrm{M}$ Al. The stimulation by low concentrations of $\mathrm{Al}$ in the population collected from the neutral $\mathrm{pH}$ site may be due to of low concentrations of $\mathrm{Al}$ reducing the toxic effects of $\mathrm{H}^{+}$on these isolates (Kinraide, 1993). More significantly, however, isolates that originated from the Al-rich soil at Dundee were not more tolerant of $\mathrm{Al}$ than were the Georgetown isolates.

With respect to $\mathrm{pH}$, our results suggested that growth of W. mikolae isolates in both populations was reduced at $\mathrm{pH} 4$ compared to that observed at the higher $\mathrm{pHs}$ of 6 and 8 (Fig. 2-4). These results suggest that isolates originating from the acidic Dundee site were not more acid tolerant than from the alkaline Georgetown site. Conversely, isolates from Georgetown were no more adapted to alkaline $\mathrm{pH}$ than isolates from Dundee. In contrast to these findings for W. mikolae, Jongbloed and Borst-Pauwels (1992) found that the optimal ranges for growth for Lactarius rufus and Lactarius hepaticus were 
between the ranges of 2.5 to 4.3 and 3.0 to 4.3 , respectively. They also found severe inhibition of these two fungi when exposed to $\mathrm{pH}$ 5.2.

Ecotypic separation appears to be absent between the Dundee and Georgetown populations, at least as it relates to soil $\mathrm{pH}$ and $\mathrm{Al}$ concentration. Perhaps the soil conditions at Dundee did not impose severe pressure to select acid-tolerant or Al-tolerant individuals. One isolate 71-10-2, was more acid-tolerant and also was genetically separated from other isolates based on AFLP analysis. However, if this species were at a competitive advantage on this site, then it would have been detected much more frequently on the Dundee plots. 


\section{REFERENCES}

Baar, J., T.R. Horton, A.M. Kretzer, and T.D. Bruns. 1999. Mycorrhizal colonization of Pinus muricata from resistant propagules after a stand replacing wildfire. New Phytol. 143: 409-418.

Barker, J.H.A., M. Matthes, G.M. Arnold, K.J. Edwards, I. Ahman, S. Larsson, and A. Karp. 1999. Characterisation of genetic diversity in potential biomass willows (Salix spp.) by RAPD and AFLP analyses. Genome 42: $173-183$.

Baxter, J.W., S.T.A. Pickett, M.M. Carreiro, and J. Dighton. 1999. Ectomycorrhizal diversity and community structure in oak forest stands exposed to contrasting anthropogenic impacts. Can. J. Bot. 77: 771-782.

Chakravarty, P., P.F. Jacobs, and R.L. Peterson. 1990. Effect of the fungicides benomyl and oxine benzoate on the mycelial growth of four isolates of E-strain fungi in vitro. Eur. J. For. Path. 20: 381-385.

Chichester, F.W. and V. L. Hauser. 1991. Change in chemical properties of constructed minesoils developing under forage grass management. Soil Sci. Soc. Am. J. 55: 451-459.

Cumming, J.R. and L.H. Weinstein. 1990. Aluminum-mycorrhizal interactions in the physiology of pitch pine seedlings. Plant and Soil 125: 718.

Cumming, J.R., T.D. Swiger, B.S. Kurnik, and D.G. Panaccione. In review. Mechanisms of aluminum tolerance in Laccaria bicolor and Pisolithus tinctorius in vitro. Can. J. For.

Danielson, R.M. 1982. Taxonomic affinities and criteria for identification of the common ectendomycorrhizal symbiont of pines. Can. J. Bot. 60: 7-18.

Danielson, R.M. and S. Visser. 1990. The mycorrhizal and nodulation status of container-grown trees and shrubs reared in commercial nurseries. Can. J. For. Res. 20: 609-614.

Egerton-Warburton, L.M. and B.J. Griffin. 1995. Differential responses of Pisolithus tinctorius isolates to aluminum in vitro. Can. J. Bot. 73: 12291233. 
Egger, K.N. 1996. Molecular systematics of E-strain mycorrhizal fungi: Wilcoxina and its relationship to Tricharina (Pezizales). Can. J. Bot. 74: 773-779.

Egger, K.N, R.M. Danielson, and J.A. Fortin. 1991. Taxonomy and population structure of E-strain mycorrhizal fungi inferred from ribosomal and mitochondrial DNA polymorphisms. Mycol. Res. 95: 866-872.

Evangelou, V.P., J.H. Grove, and F.D. Rawlings. 1985. Rates of iron sulfide oxidation in coal spoil suspensions. J. Environ. Qual. 14: 91-94.

Felsenstein, J. 1993. PHYLIP (Phylogeny Inference Package) version 3.5c. Distributed by the author. Department of Genetics, University of Washington, Seattle.

Gehring, C.A., T.C. Theimer, T.G. Whitham, and P. Keim. 1998. Ectomycorrhizal fungal community structure of pinyon pines growing in two environmental extremes. Ecology 79: 1562-1572.

Grauer, U.E. 1992. Modeling cation amelioration of aluminum phytotoxicity. Soil Sci. Soc. Am. J. 56: 166-172.

Jongbloed, R.H. and G.W.F.H. Bortst-Pauwels. 1992. Effects of aluminum and $\mathrm{pH}$ on growth and potassium uptake by three ectomycorrhizal fungi in liquid culture. Plant and Soil 140: 157-165.

Jongbloed, R.H., M.W.A. Tosserams, and G.W.F.H. Bortst-Pauwels. 1992. The effect of aluminum on phosphate uptake by three isolated ectomycorrhizal fungi. Plant and Soil 140: 167-174.

Kinraide, T.B. 1993. Aluminum enhancement of plant growth in acid rooting media. A case of reciprocal alleviation of toxicity by two toxic cations.

Physiol. Plant. 88: 619-625.

Marx, D.H. 1969. The influence of ectotrophic mycorrhizal fungi on the resistance of pine roots to pathogenic infections. I. Antagonism of mycorrhizal fungi to root pathogenic fungi and soil bacteria. Phytopathology 59: 153-163.

Molina, R. and J.G. Palmer. 1982. Isolation, maintenance, and pure culture manipulation of ectomycorrhizal fungi. In Methods and Principles of Mycorrhizal Research. Edited by N.C. Schenck. American Phytopathological Society, St. Paul, MN. pp. 115-129. 
Panaccione, D.G., N.L. Sheets, S.P. Miller, and J.R. Cumming. In review. Divergence of Cenococcum geophilum isolates from serpentine and nonserpentine soils. Mycologia

Sambrook, J., E.F. Fritsch, and T. Maniatis. 1989. Molecular cloning: a laboratory manual. $2^{\text {nd }}$ Ed. Cold Spring Harbor Laboratory Press, Cold Spring Harbor, N.Y.

Scales, P.F. and R.L. Peterson. 1991a. Structure of ectomycorrhizae formed by Wilcoxina mikolae var. mikolae with Picea mariana and Betula alleghaniensis. Can. J. Bot. 69: 2149-2157.

Scales, P.F. and R.L. Peterson. 1991b. Structure and development of Pinus banksiana-Wilcoxina ectendomycorrhizae. Can. J. Bot. 69: 2135-2148.

Sanchez, G., S. Restrepo, M.C. Duque, M. Fregene, M. Bonierbale, and V. Verdier. 1999. AFLP assessment of genetic variability in cassava accessions (Manihot esculenta) resistant and susceptible to the cassava bacterial blight (CCB). Genome, 42: 163-172.

Shishido, M., H.B. Massicotte, and C.P. Chanway. 1996. Effect of plant growth promoting Bacillus strains on pine and spruce seedlings growth and mycorrhizal infection. Ann. Bot. 77: 433-441.

Thomson, G.W. and R.J. Medve. 1984. Effects of aluminum and manganese on the growth of ectomycorrhizal fungi. Appl. Environ. Microbiol. 48: 556560 .

Weising, K., H. Nybom, K. Wolff, and W. Meyer. 1995. DNA fingerprinting in plants and fungi. CRC Press, Boca Raton.

Wilden, R. W. Schaaf, and R.F. Huttl. 1999. Soil solution chemistry of two reclamation sites in the Lusatian lignite mining district as influenced by organic matter application. Plant and Soil. 213: 231-340.

White, T.J., T.D. Bruns, S.B. Lee, and J.W. Taylor. 1990. Amplification and direct sequencing of fungal ribosomal RNA genes for phyologenetics. In PCR protocols - a guide to methods and applications. Edited by M.A. Innis, D.H. Gelfand, J.J. Sninsky, and T.J. White. Academic Press, New York. pp. 315322.

Yang, C.S. and R.P. Korf. 1985. A monograph of the genus Tricharina and of a new segregate genus, Wilcoxina (Pezizales). Mycotaxon, 24: 467-531. 
Yang, C.S. and H.E. Wilcox. 1984. An E-strain ectendomycorrhiza formed by a new species, Tricharina mikolae. Mycologia, 76: 675-684.

Zel, J., J. Svetek, H. Crne, and M. Schara. 1993. Effects of aluminum on membrane fluidity of the mycorrhizal fungus Amanita muscaria. Physiol. Plant. 89: 172-176.

Zeleznik, J.D. and J.G. Skousen. 1996. Survival of three tree species on old reclaimed surface mines in Ohio. J. Environ. Qual. 25: 1429-1435. 


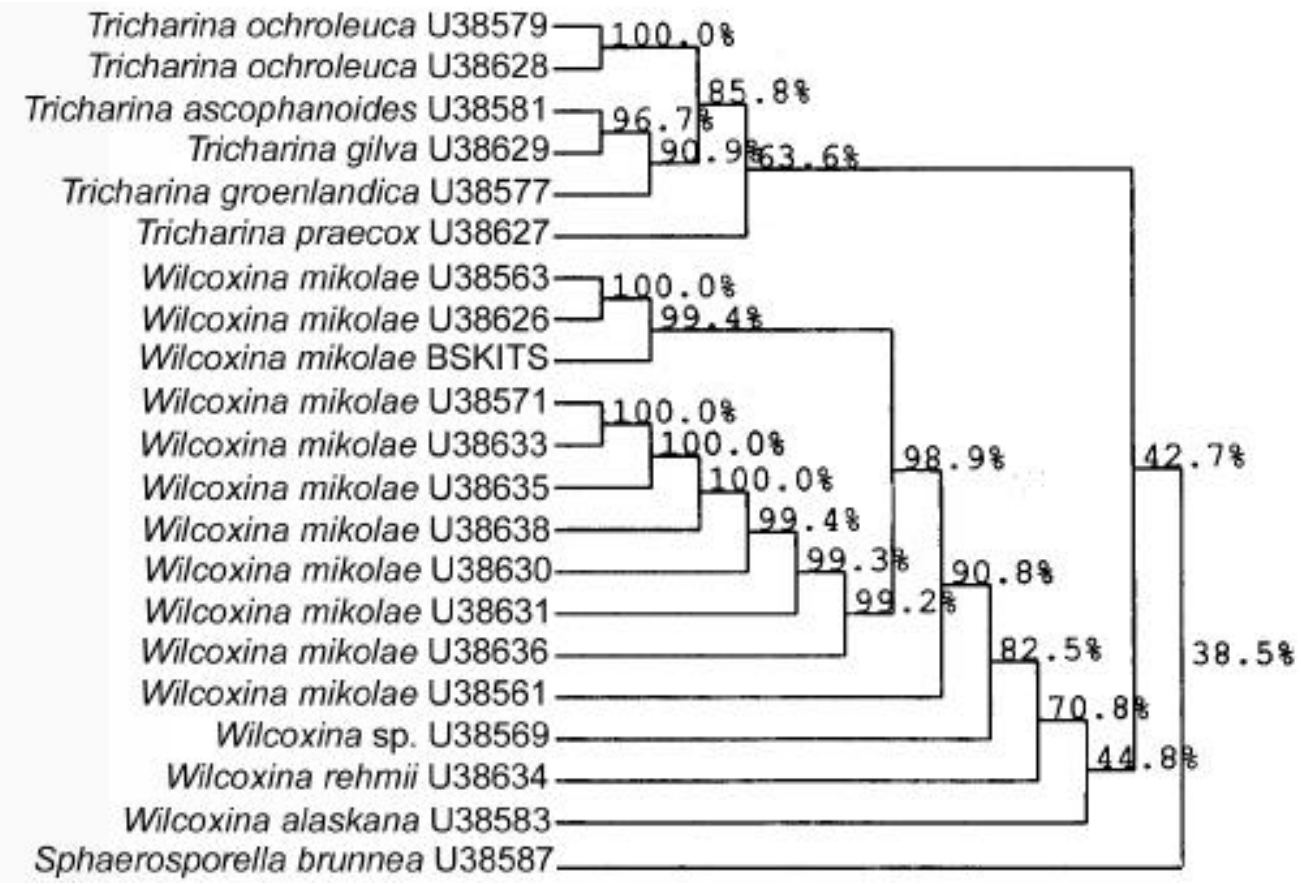

Figure 2-1. DNA sequence comparison of the ITS region.

Comparison of the DNA sequence of the ITS region of the 'rust brown' fungus (BSKITS) with the ITS regions of Wilcoxina mikolae and related fungi. Isolate designations are GenBank accession numbers. Figures at nodes are percent DNA sequence identity. Tree was generated by the multiple alignment algorithm of DNASIS for Windows 2.0. 

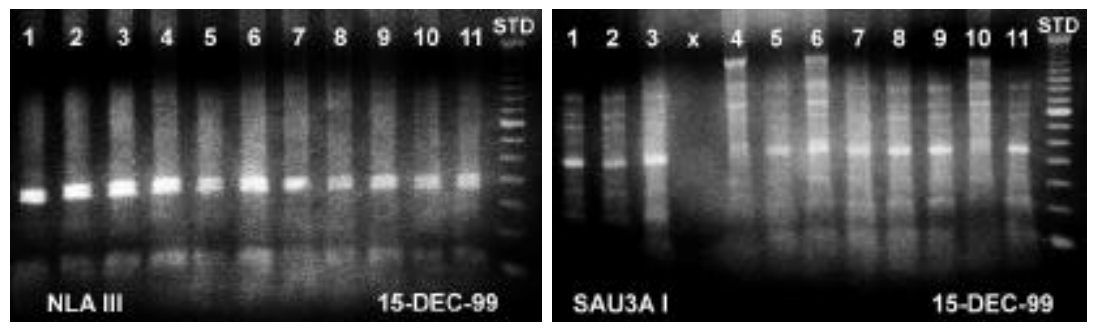

Figure 2-2. Second generation of W. mikolae RFLP patterns.

RFLP patterns of the second-generation $W$. mikolae ITS regions amplified with ITS1 and ITS4 and digested with Sau 3AI and Nla III. Comparison of RFLP patterns between second-generation mycorrhizal root tips of $W$. mikolae and also the trap culture isolate A230 (Lane 11). Lane $1=$ tree 1 root tip $a$, lane $2=$ tree 1 root tip $b$, lane $3=$ tree 4 root tip $a$, lane $4=$ tree 4 root tip $b$, lane $5=$ tree 5 root tip $a$, lane $6=$ tree 5 root tip $b$, lane $7=$ tree 6 root tip $a$, lane $8=$ tree 6 root tip $b$, lane $9=$ tree 7 root tip $a$, lane $10=$ tree 7 root tip $b$, lane $11=\mathrm{A} 230$, and $\mathrm{Std}=50$ base pair ladder from GIBCO BRL. 


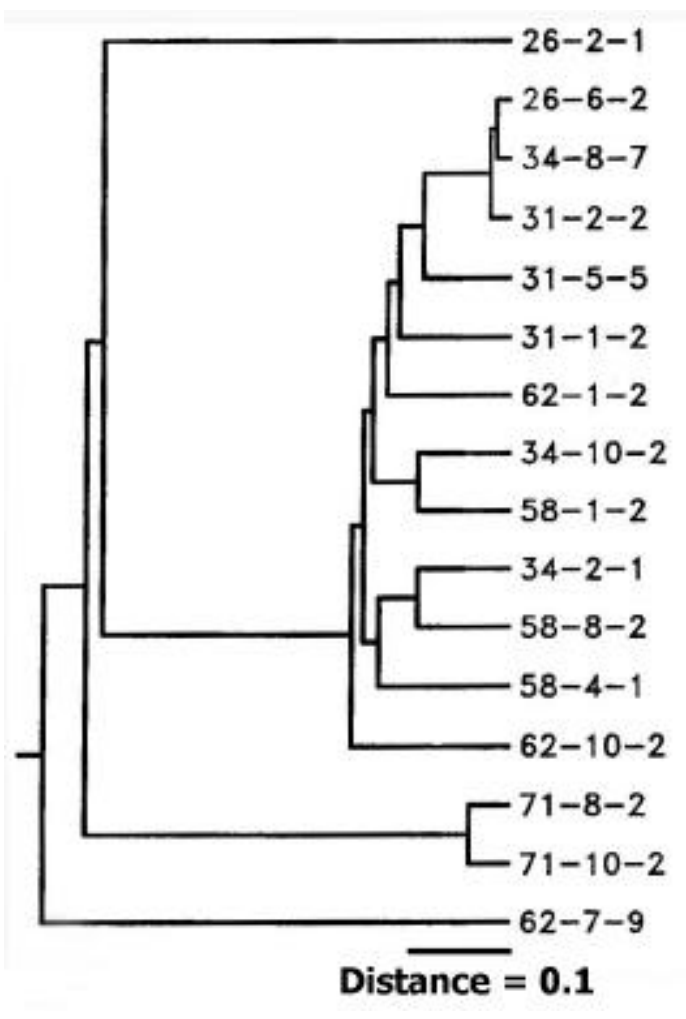

Figure 2-3. Isolate relationship based upon distance matrix.

Relationships of isolates based upon distance matrix of polymorphic bands created by four AFLP primer pairs. The tree was generated by the UPGMA (Unweighted Pair Group Maximum Averages) algorithm of PHYLIP (Phylogeny Inference Package). The first number represents the plot in which the fungus was found (26, 31, 34 for Georgetown; 58, 62, 71 for Dundee). The middle number represents the tree number in which the isolates were found. Finally, the last number represents the root morphotype. 


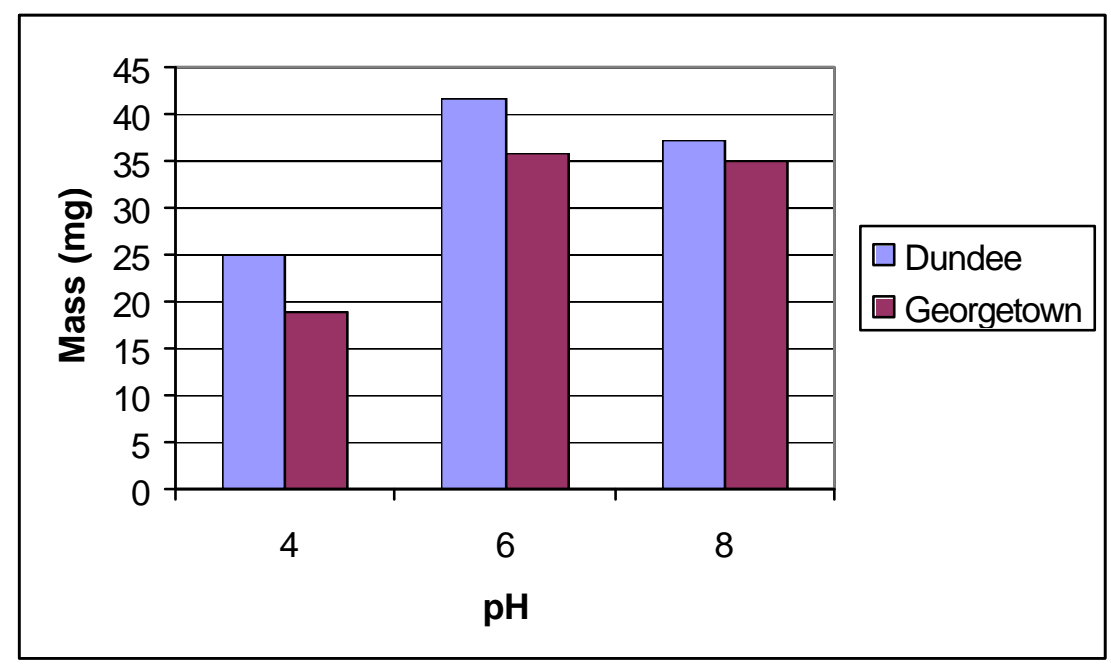

Figure 2-4. Dry weight of $W$. mikolae isolates in response to $\mathrm{pH}$.

Dry weight of $W$. mikolae isolates grown in MMN media with $\mathrm{pH}$ treatment of 4,6 , and 8 . Bars represent the means of 4 replicates. 


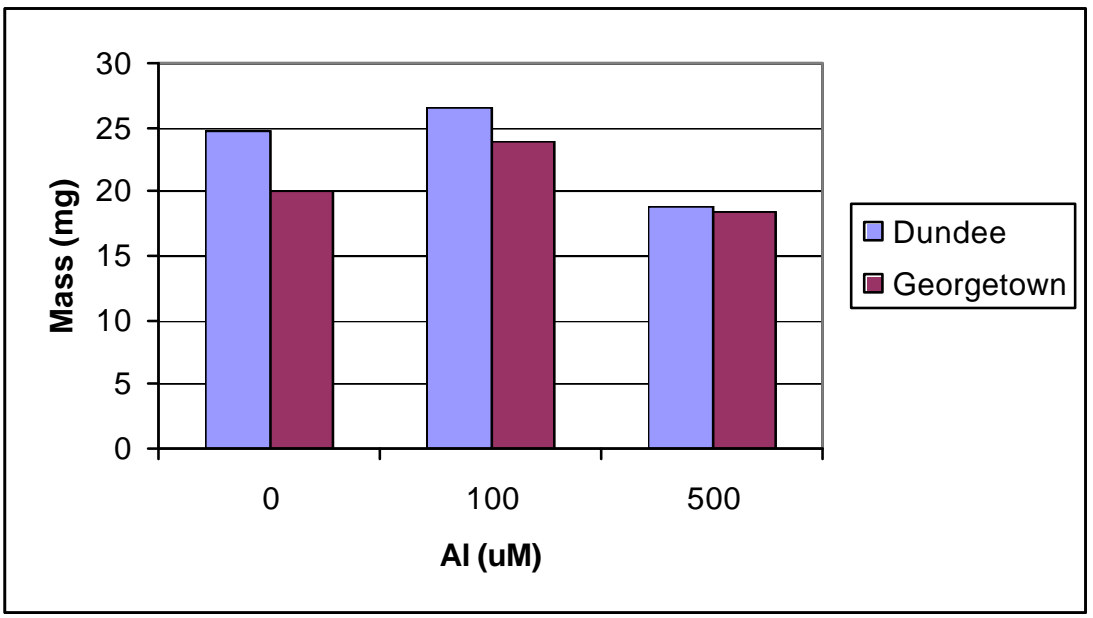

Figure 2-5. Dry of W. mikolae isolates in response to Al.

Dry weight of W. mikolae isolates grown in $\mathrm{MMN}$ media with $\mathrm{Al}$ treatments of $0,100 \mu \mathrm{M} \mathrm{Al}$, and $500 \mu \mathrm{M} \mathrm{Al}$. Bars represent the means of 4 replicates. 


\section{Appendix A}

\section{Miniprep Extraction Method (Gardes and Bruns, 1993)}

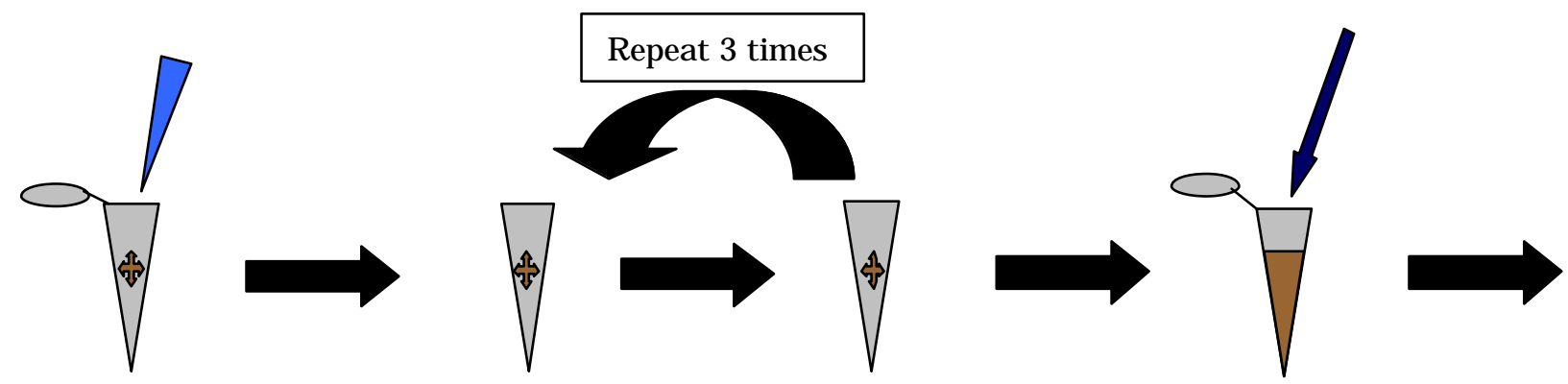

Add $300 \mu \mathrm{l}$ of $2 \mathrm{X}$ CTAB extraction buffer to frozen root tip.

Freeze at $-80 \mathrm{C}$.

Thaw at $65 \mathrm{C}$.

Crush with a micropestle and incubate at $65 \mathrm{C}$ for 30 to 60 minutes.

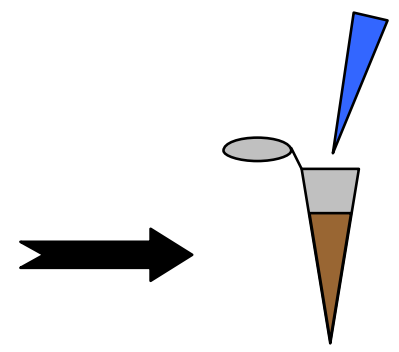

Add $300 \mu \mathrm{l}$ of chloroform, shake briefly, and centrifuge for 10 minutes.
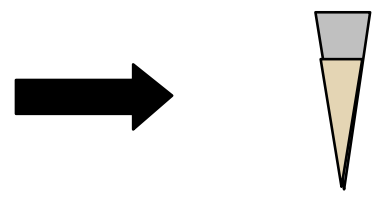

Transfer top layer to new tube.

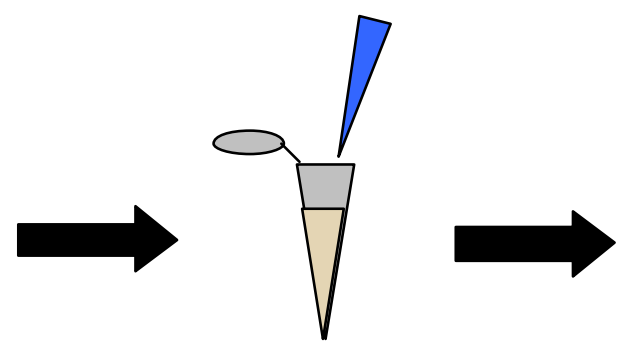

Add one volume of cold isopropanol and incubate overnight at $-20 \mathrm{C}$.

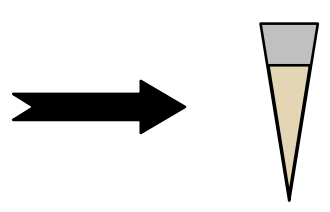

Next day, centrifuge 10 minutes to form small pellet in bottom of microfuge tube.
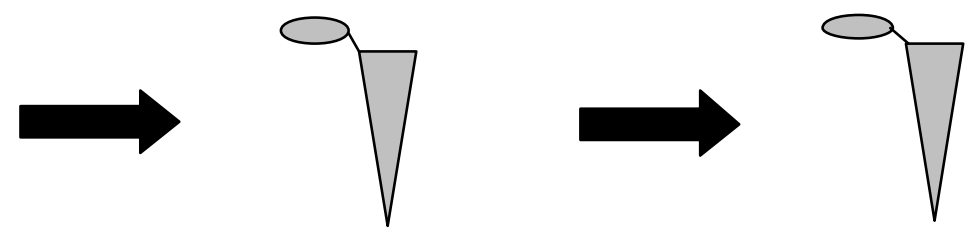

Discard supernatant, dry pellet in speed vacuum for 5 minutes, resuspend pellet in 40 to $60 \mu \mathrm{l}$ of $0.1 \mathrm{X}$ $\mathrm{TE}$ and store at $-20 \mathrm{C}$. 


\section{Appendix B}

\section{GeneClean Protocol}

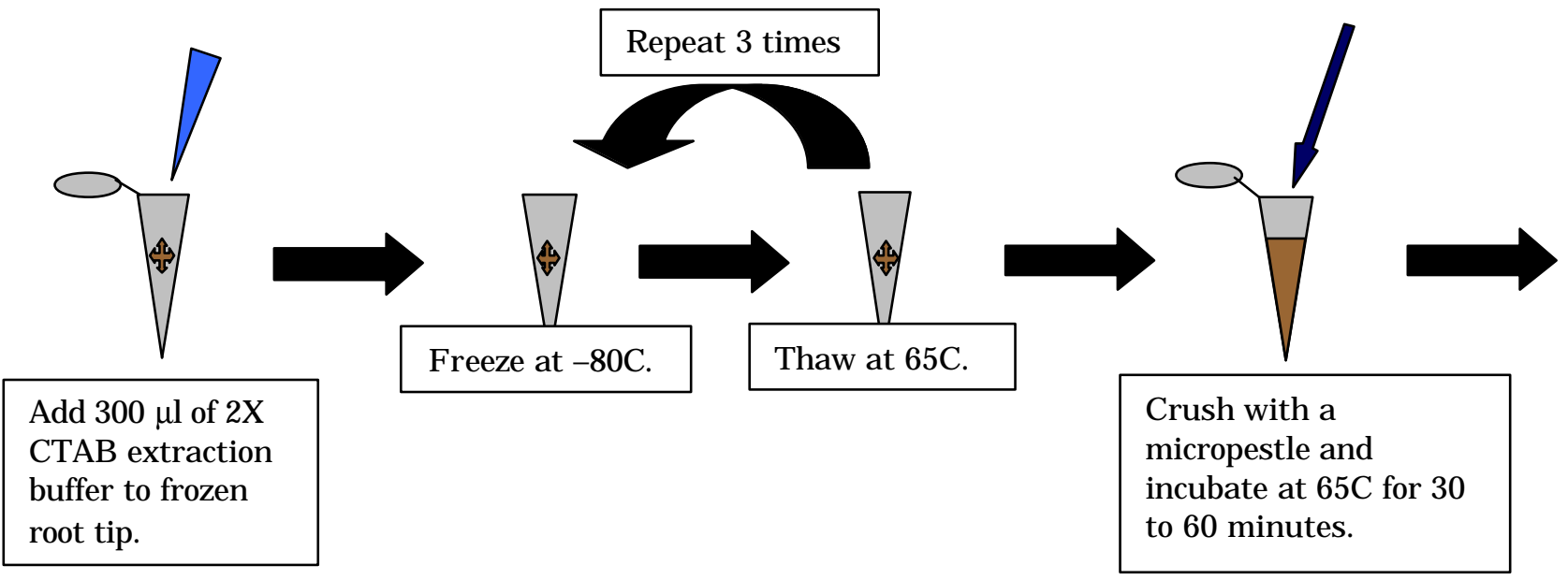

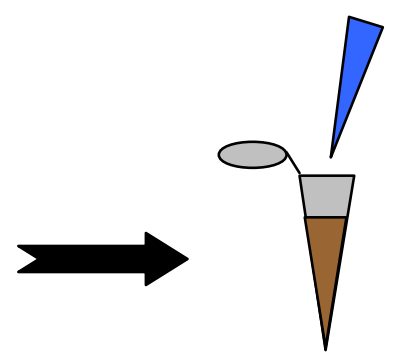

Add $300 \mu \mathrm{l}$ of chloroform, shake briefly, and centrifuge for 10 minutes.

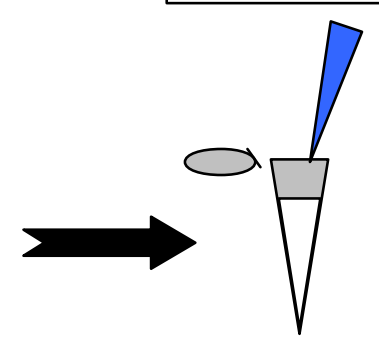

Wash pellet with $500 \mu \mathrm{l}$ of New Wash, spin for 5 seconds, discard supernatant. Repeat.

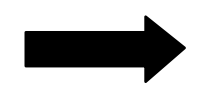

Transfer top layer to new tube. Add 3 volumes of $\mathrm{NaI}$ solution.

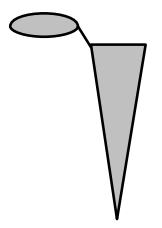

Dry pellet in speed vacuum for 2 to 5 minutes.
Resuspend pellet in 40 $\mu \mathrm{l}$ of TE, centrifuge for 30 seconds, decant supernatant, put in new tube, and store at $-20 \mathrm{C}$. 


\section{Appendix C}

\section{GeneClean Spin Protocol}

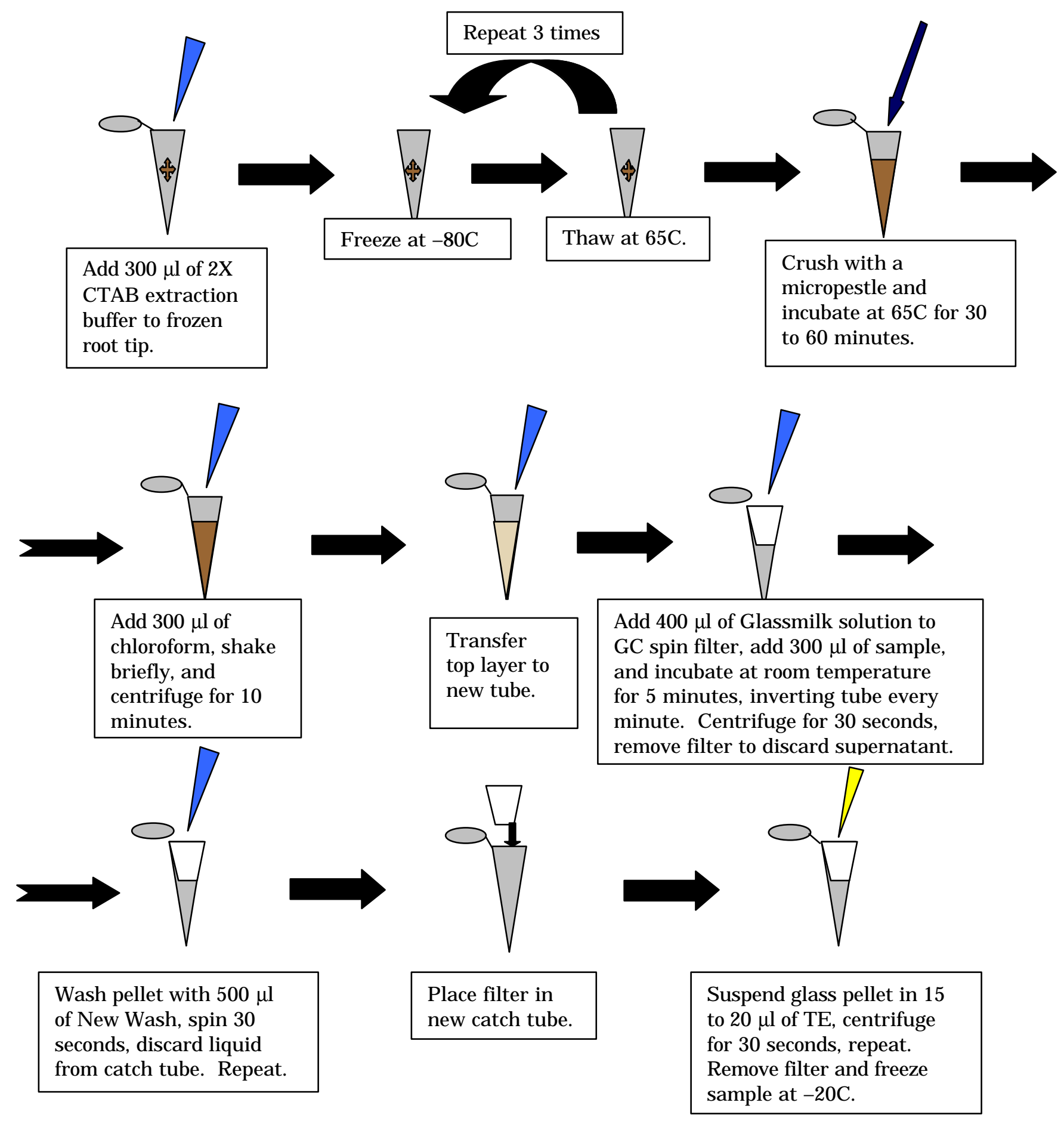

